\title{
Impact of neighbourhood-scale climate characteristics on building heating demand and night ventilation cooling potential
}

Article

Accepted Version

Creative Commons: Attribution-Noncommercial-No Derivative Works 4.0

Xiaoxiong, X., Sahin, O., Luo, Z. and Yao, R. (2020) Impact of neighbourhood-scale climate characteristics on building heating demand and night ventilation cooling potential.

Renewable Energy, 150. pp. 943-956. ISSN 0960-1481 doi: https://doi.org/10.1016/j.renene.2019.11.148 Available at https://centaur.reading.ac.uk/87507/

It is advisable to refer to the publisher's version if you intend to cite from the work. See Guidance on citing.

To link to this article DOI: http://dx.doi.org/10.1016/j.renene.2019.11.148

Publisher: Elsevier

All outputs in CentAUR are protected by Intellectual Property Rights law, including copyright law. Copyright and IPR is retained by the creators or other copyright holders. Terms and conditions for use of this material are defined in the End User Agreement. 


\section{CentAUR}

Central Archive at the University of Reading

Reading's research outputs online 
1 Manuscript revised to Renewable Energy revised Nov 2019

2

\section{Impact of neighbourhood-scale climate characteristics on building} heating demand and night ventilation cooling potential

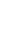

Word count of abstract: 314

Word count of text: 5,652

*Author for correspondence:

Dr Zhiwen Luo, School of the Built Environment, University of Reading, United Kingdom Email:z.luo@reading.ac.uk 
Abstract: As buildings are main contributor to greenhouse gas emissions, it is important to assess the performance of existing buildings and assist the design of new sustainable buildings through building energy simulation. It is well known that by using local climate measurements for building energy simulation would provide more accurate result than by using other typical weather data, i.e. typical meteorological year (TMY). However, as different built forms/architectural layouts would also have impacts on neighbourhood-scale microclimate, it is worthy to quantify the difference it would make. In this study, we performed a year-long measurement with four weather stations surrounding a campus building in 2009 and 2010. Each station was placed in a typical type of built form, including a street canyon, a courtyard, a semiclosed courtyard and a relatively larger open area. Besides, two typical weather data files, typical meteorological year (TMY) and actual meteorological year (AMY) were taken as reference. Annual heating demand and natural ventilation cooling potential were calculated based on all 6 weather files. Our simulation results show that the variation in annual heating demand of different built forms could be between $1.1-7.3 \%$, where the large open area has the highest heating demand and it of the courtyard is the lowest. The difference between on-site measurement and TMY in annual heating load is as high as 10.8\%. While in summer, night ventilation cooling potential of the courtyard and the semi-closed form are the highest, and it of the street canyon is the lowest. Using TMY could underestimate the night ventilation cooling potential by $26-31 \%$ and using AMY could overestimate it by $9-14 \%$ in total. Overall speaking, the courtyard form shows good performance in reducing heating demand and enhancing night ventilation cooling, while the street canyon shows relatively poor performance in both aspects. These findings highlight the importance to understand the impact of neighbourhood-scale microclimate on building energy performance. 
Keywords: Built forms; Neighbourhood scale microclimate; Night ventilation cooling; Building heating demand; Typical meteorological year

\section{Introduction}

In the UK, buildings are responsible for $19 \%$ of annual greenhouse gas emissions [1], while space and water heating in domestic buildings account for $80 \%$ of total building energy consumption [2]. Building energy simulation plays a crucial role in the renovation of existing buildings and the development of new energy and cost-efficient buildings. The main factors determining the energy use in buildings include the climate, envelope, energy systems, occupant behaviour, operation and maintenance, and indoor environmental quality requirements [3]. Of them, weather information is of paramount importance for the accurate prediction of a building's energy use and environmental performance.

It is generally believed that using on-site weather data obtained by local monitoring for building energy simulation will provide more accurate results than those obtained from remote rural site such as airport especially for buildings located in dense urban areas[4]. The urban heat island ( $\mathrm{UHI}$ ) effect is a result of distinctive urban features in contrast to its rural counterpart such as more compact urban form, urban material with higher thermal capacity, and more intense human activities [5]. Because of the existence of UHI, using rural weather data for urban building energy simulation will lead to a certain extent of bias. Many studies showed that the increase in cooling demand of urban buildings due to $\mathrm{UHI}$ is around $10 \%$ to $120 \%$, with a medium value of $19 \%$, while the decrease in heating demand in around $3 \%$ to $45 \%$, with a medium value of $18.7 \%$ $[6-12]$.

In urban areas, buildings are located within complex neighbourhood and surrounded by various types of built forms/architectural layouts. Impacts of built forms like street canyon and 
courtyard on local microclimate characteristics have been investigated by many researchers during past decades for different climates in the world [13-18]. Within the smaller neighbourhood scale, radiation trapping and wind sheltering effects caused by built forms would have an influence on the building energy consumption [5]. Strømann-Andersen and Sattrup [19] reported that in Copenhagen, a street canyon with higher aspect ratio would increase total building energy consumption including heating, cooling and lighting. Study by Allegrini et al. [20] demonstrated that for new buildings, comparing a building in the street canyon with a stand-alone one, the decrease in heating demand could be around $20 \%$ and the increase in cooling demand is about $700 \%$ in Swiss city of Basel. This is suggested to be a result of solar irradiance trapped between building façades, and the low convective heat transfer coefficient in the canyon resulting from wind shelters. Ratti et al. [21] suggested that climate type should be considered as the thermal function of courtyard could be different under hotarid and hot-humid climate. Muhaisen and Gadi [22] found that deep courtyard could help to reduce cooling load in summer with shading, and heating load in winter with heat trapping, under mild climate in Roma. Shashua-Bar et al. [23] focused on three types of built forms: a conventional street form with space between houses, a street canyon, and a courtyard in TelAviv, Israel. Their study found that there were linear relationships between the envelope ratio and the thermal effects of the built form, vegetation and colonnades. As most of existing studies focused on single type of built form and used ENVI-met for climate parameter simulation, further studies based on field measurement for various typical built form would be valuable to generate new insight on this issue. .

Similar with the heating and cooling load, natural ventilation cooling potential is also largely influenced by neighbourhood scale microclimate, as wind- and heat-driven natural ventilation mainly depend on the external wind characteristics and air temperature. Geros et al. [24] and Santamouris et al. [25] highlighted that the natural ventilation cooling potential inside street canyons would decrease because of the higher temperature and lower wind speed. In 
contrast with street canyons, the courtyard form is generally believed to enhance passive cooling, especially in hot regions [26]. Toe and Kubota [27] investigated two features of courtyard passive cooling in hot-humid region: 1) maintaining a cool outdoor microclimate and reducing the temperature of the outdoor air before entering the lightweight house for cooling by cross ventilation; 2) cooling the high thermal mass structures through nocturnal ventilation and radiative cooling. Moonen et al. [28] analysed the airflow inside street canyon and courtyard through CFD simulation, but the difference in cooling energy saving was not quantified.

According to above literature review, it is well known that different types of built forms would change local microclimate, and further influence surrounding building energy consumption. However, there is a lack of research comparing various built form types under the same real-world circumstance, as most of the existing studies are either based on idealised models $[21,23,28]$, or focused on one certain type of built form $[16,19,22]$. In this study, we conducted a year-long monitoring of microclimate characteristics of four built forms, i.e., courtyard, street canyon, semi-closed courtyard, and large courtyard with open green space, that are all located around the same building at the campus of University of Reading, UK. The objective of this paper is to reveal the differences in building heat demand (winter) and natural ventilation cooling potential (summer) due to neighbourhood microclimate diversity by combining urban microclimate measurement and building energy simulation. It is important to be noted that in this study, each built form should be considered in the context of its surroundings, instead of taken as an individual space. Results of this study could serve as a reference for relevant future work for understanding the impact of neighbourhood-scale microclimate on building performance in other climates and cities.

\section{Methods}

\subsection{On-site monitoring}


This study employed weather data collected from four types of built forms to simulate the building energy performance of a faculty building (URS building) on the University of Reading campus, Reading, UK. Four Davis Vantage Pro2 wireless weather stations (as shown in Fig. 1) were located surrounding the URS building at pedestrian level and $3.5 \mathrm{~m}$ above the ground. Environmental parameters including dry-bulb temperature, relative humidity, global solar radiation, wind direction and wind speed were monitored continuously from $1^{\text {st }}$ April 2009 to $31^{\text {st }}$ March 2010 with a total length of one year. Each station represents one type of architectural layout/built form: a larger relatively open-space in a low-rise building complex (MS1), a street canyon (MS2), a semi-closed courtyard (MS3), a courtyard (MS4), with the H/W ratio shown in

Table 1. Heights of building blocks URS, A, B, C, D, E and F are $12 \mathrm{~m}, 7 \mathrm{~m}, 7 \mathrm{~m}, 7 \mathrm{~m}, 3 \mathrm{~m}, 12 \mathrm{~m}$ and $18 \mathrm{~m}$, respectively. Measurements were taken at 5-mintue intervals, and all five-minute data batches were converted into hourly data by taking the average value of each hour for later energy simulation.

Table 1: Characteristics of on-site monitoring stations.

\begin{tabular}{lll}
\hline On-site measurement & Location of measurement station & H/W ratio \\
\hline Measurement station 1 (MS1) & Large open area & 0.14. \\
Measurement station 2 (MS2) & Street canyon & 0.66 \\
Measurement station 3 (MS3) & Semi-closed courtyard & 0.20 \\
Measurement station 4 (MS4) & Courtyard & 0.38 \\
\hline
\end{tabular}



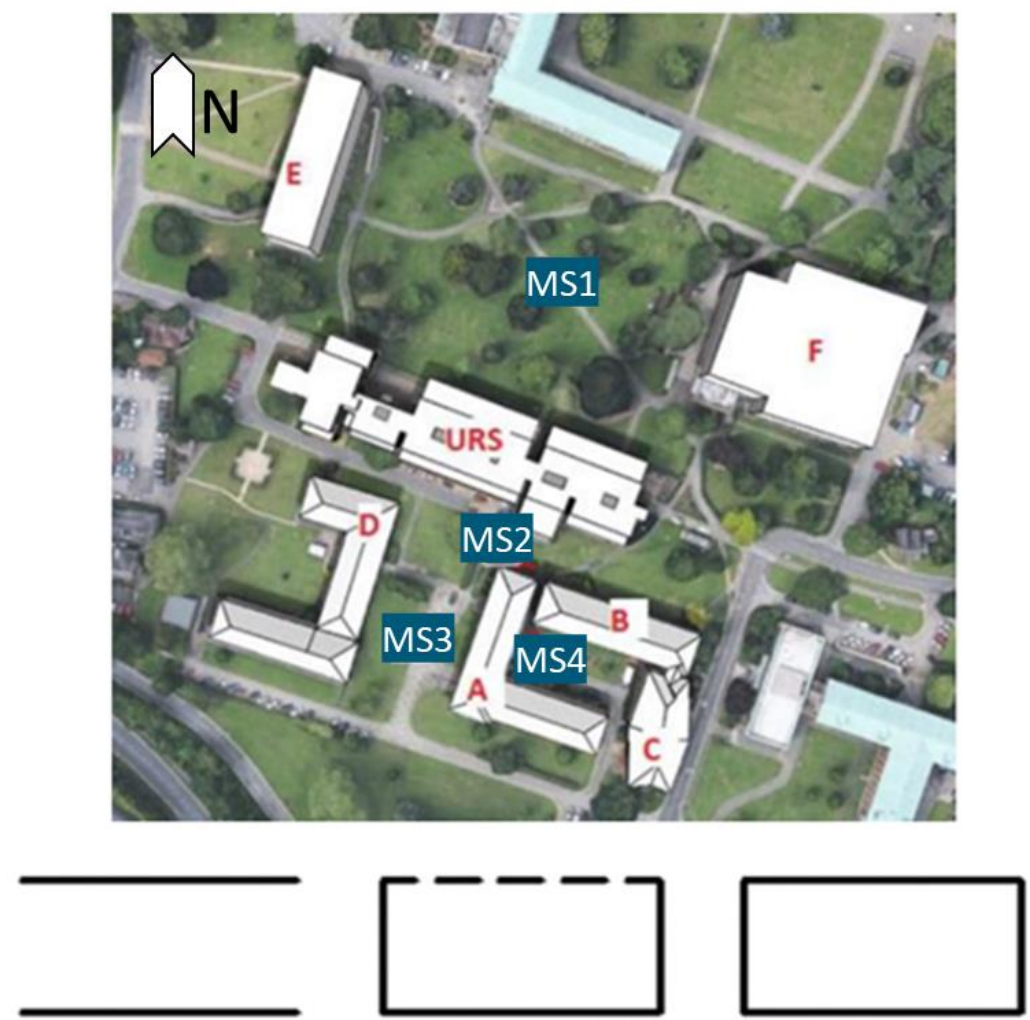

MS2: Street canyon MS3: Semi-closed courtyard MS4: Courtyard

Fig. 1: Layout of monitoring stations and buildings surrounding the URS building.

\subsection{Reference weather data}

Two reference weather data sources including typical meteorological year (TMY) and

reanalysed weather data were also used in addition to on-site monitoring. TMY weather file was obtained from the EnergyPlus weather database, which contains typical weather data suitable for energy simulation programmes and available for 10 locations in the UK [29]. This meteorological file is based on the data record at Gatwick Airport Weather Station, which is the closest TMY meteorological measurement point to Reading, at a distance of about $78 \mathrm{~km}$.

Reanalysed weather data was obtained from the SHINY Weather Data [30], which is a web service providing gridded hourly weather data by the Swedish Meteorological and Hydrological Institute (SMHI) and Copernicus Atmosphere Monitoring Service (CAMS). SHMI utilises a mesoscale analyses system called MESAN, which is based on statistical interpolation for each studied meteorological parameter. MESAN data for this case are based on an $11 * 11 \mathrm{~km}$ grid 
centred on Reading. Copernicus Atmosphere Monitoring Service (CAMS) provides time series of global, direct and diffuse irradiations [31].

\subsection{Simulation tool}

The research is based on the quantitative method of building simulation in terms of understanding the energy performance of the URS building by using weather data from different built forms. Dynamic thermal simulation software IES-VE 2017 (feature pack 4) was used in this study for heating load and natural ventilation cooling potential modelling. [32]. IES-VE is commonly used and well-established for building energy demand modelling and natural ventilation simulation [33-37].

The programme CIBSE Heat Loss \& Gain (ApacheCalc) integrated within IES-VE was used to compute the heat loss and gain according to the procedures specified in CIBSE Guide A [38,39]. Heating load is calculated by following CIBSE procedure that considers plant size and steadystate room heat losses that are calculated in the absence of casual and solar heat gains. The programme applies CIBSE Simple Method (see CIBSE Guide A, $7^{\text {th }}$ edition, Section 5.6.2) to calculate the sum of the fabric and ventilation losses using Eq.1:

$$
\Phi_{t}=\left[F_{1 c u} \sum(A U)+F_{2 c u} C_{v}\right]\left(\theta_{c}-\theta_{a o}\right)
$$

where $\Phi_{t}$ is the total heat loss $(\mathrm{W}), F_{1 c u}$ and $F_{2 c u}$ are factors related to characteristics of the heat source with respect to operative temperature, $\sum(A U)$ is sum of the products of surface area and corresponding thermal transmittance over surfaces through which heat flow occurs $\left(\mathrm{W} . \mathrm{K}^{-1}\right), C_{v}$ is the ventilation conductance $\left(\mathrm{W} \cdot \mathrm{K}^{-1}\right), \theta_{c}$ is the operative temperature at centre of room $\left({ }^{\circ} \mathrm{C}\right)$ and $\theta_{a o}$ is the outside air temperature $\left({ }^{\circ} \mathrm{C}\right)$.

Computational fluid dynamics (CFD) and multi-zone airflow network (AFN) modelling are two most commonly used approaches for assessing natural ventilation performance, but they serve different purposes. CFD simulation could provide detailed spatial distributions of air 
174 velocity, air pressure, temperature, contaminant concentration and turbulence by numerically

175 solving the governing conservation equations of fluid flows [40]. Although CFD or coupling CFD-

176 AFN simulations are believed to provide more accurate result in natural ventilation potential

177 [41-43], it relies largely on a powerful computer and is time-consuming, especially for largescale multiple zone models like the URS building in this study $[40,44,45]$. AFN is normally used in building energy simulation tools such as IES-VE and EnergyPlus. In AFN model, a building is represented by zones and linkage elements (windows, doors, cracks etc.) [46]. Within any single zones in multizone AFN model, the air temperature distribution is taken as uniform, and momentum effects are simplified by means of power law equations [47]. The AFN approach is reported to achieve the balance between the accuracy and computational cost [45]. As the whole building needs to be modelled, and the aim of this study is to compare the different impacts of built forms on building energy demand instead of predicting the natural ventilation accurately, AFN model is considered more suitable to be used. programme integrated in IES-VE [39]. MacroFlo considers both wind-driven and buoyancydriven natural ventilation, and calculates the air flow rate through cracks and large openings, as well as air flow balance between neighbouring zones inside the building [39]. After the air mass flow rate through the window opening is simulated, the ventilation heat loss will be calculated by using Eq.2:

where $\Phi_{v}$ is the heat transfer by ventilation $(\mathrm{W}), q_{v}$ is the volumetric flow rate through opening 195 $\left(\mathrm{m}^{3} / \mathrm{s}\right), \rho$ is the density of $\operatorname{air}\left(\mathrm{kg} / \mathrm{m}^{3}\right), C_{p}$ is the specific heat capacity of air $(\mathrm{kJ} / \mathrm{kg} . \mathrm{K}), \theta_{i}$ is the indoor temperature $\left({ }^{\circ} \mathrm{C}\right)$ and $\theta_{o}$ is the outdoor temperature $\left({ }^{\circ} \mathrm{C}\right)$. Assumptions made for this equation include: (a) $\rho=1.225 \mathrm{~kg} / \mathrm{m}^{3}$; (b) $C_{p}=1.005 \mathrm{~kJ} / \mathrm{kg} . \mathrm{K}$. 

a longitudinal footprint with four floors and a partial fifth floor. The building is formed from an exposed reinforced concrete frame which is infilled with pre-cast concrete cladding panels, aluminium panels and aluminium windows. The geometry of the building is shown in Fig. 2. An example showing the layout of $3^{\text {rd }}$ floors is shown in Fig. 3, with two office rooms selected for natural ventilation cooling potential comparison. Detailed construction and glazing material information for is shown in Table 2. The operation schedule of the URS building is based on an office schedule, whereby people are only present during working hours (9:00 - 18:00), and the equipment and lighting also work only during working hours. There is only heating system installed in the building, and the heating set-point is $19^{\circ}$

C. Internal gains from people, lighting and equipment are assumed in different space types, including the classroom, office, common area and toilets based on the unit floor area, as summarised in Table 3.

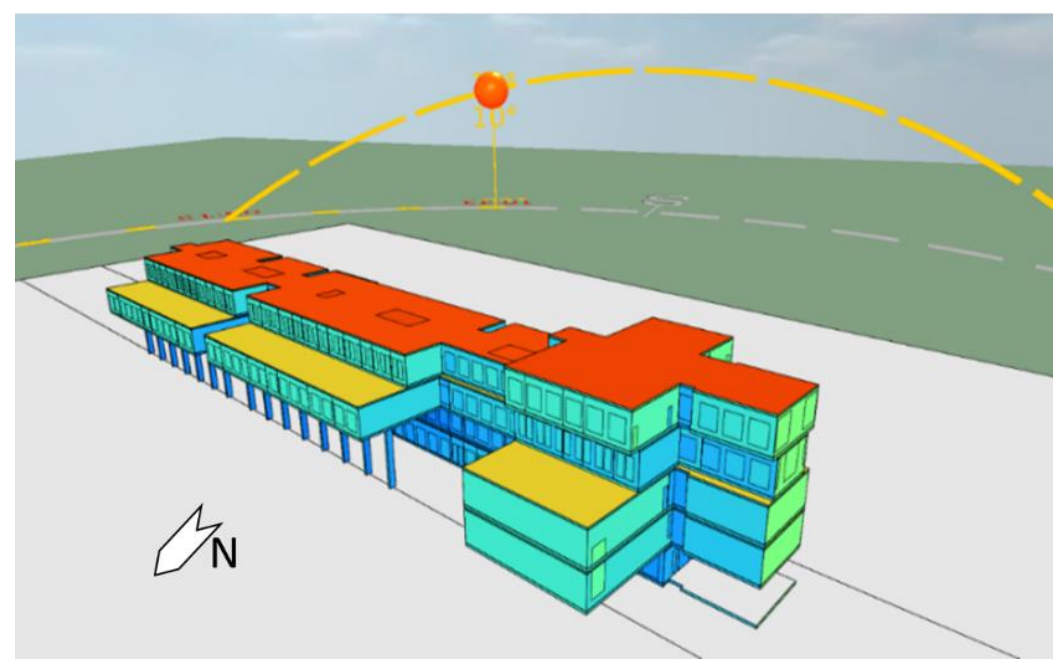

Fig. 2: Geometry of the URS building model. 


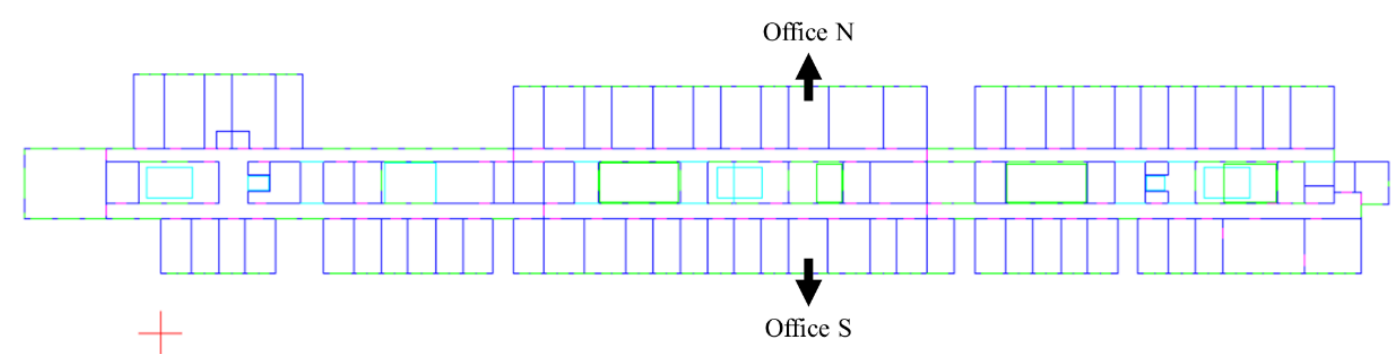

Fig. 3: Layout plan of $3^{\text {rd }}$ floor of the URS building

215 Table 2: Characteristics of the building for modelling.

\begin{tabular}{|c|c|c|}
\hline Category & $\begin{array}{l}\text { Materials (External to } \\
\text { internal) }\end{array}$ & U-value $\left(\mathrm{W} / \mathrm{m}^{2} \mathrm{~K}\right)$ \\
\hline External wall & $\begin{array}{l}\text { Precast concrete cladding } \\
\text { panels. } \\
\text { Wood wool insulation. } \\
\text { Masonry infill panels. } \\
\text { Plaster. }\end{array}$ & 1.40 \\
\hline Internal partition & $\begin{array}{l}\text { Plaster. } \\
\text { Concrete blocks. } \\
\text { Plaster. }\end{array}$ & 1.23 \\
\hline Window & $\begin{array}{l}\text { Single glazing. } \\
\text { Aluminium frame. }\end{array}$ & 5.24 \\
\hline Celling/Floor & $\begin{array}{l}\text { Chipboard flooring. } \\
\text { Cavity. } \\
\text { Screed. } \\
\text { Reinforced concrete. }\end{array}$ & 1.09 \\
\hline Ground floor & $\begin{array}{l}\text { Insulation. } \\
\text { Reinforced concrete. } \\
\text { Cavity. } \\
\text { Chipboard flooring. }\end{array}$ & 0.55 \\
\hline Roof & $\begin{array}{l}\text { Zinc sheet and ply elastomeric } \\
\text { roof covering. } \\
\text { Wood wool insulation slab. } \\
\text { Structural concrete roof deck. } \\
\text { Cavity. } \\
\text { Plasterboard. }\end{array}$ & 0.79 \\
\hline
\end{tabular}

217 Table 3: Occupancy density and internal gains of main spaces

Space type People




\begin{tabular}{|c|c|c|c|c|c|}
\hline & $\begin{array}{l}\text { Occupancy } \\
\text { ( } \mathrm{m}^{2} / \text { person) }\end{array}$ & $\begin{array}{l}\text { Sensible heat } \\
\text { gain } \\
\text { (W/person) }\end{array}$ & $\begin{array}{l}\text { Latent heat } \\
\text { gain } \\
\text { (W/person) }\end{array}$ & $\left(W / m^{2}\right)$ & $\left(W / m^{2}\right)$ \\
\hline Office & 10 & 90 & 60 & 12 & 3 \\
\hline Classroom & 3 & 90 & 60 & 10 & 3 \\
\hline Circulation area & 20 & 90 & 60 & 8 & - \\
\hline Toilet & 3 & 90 & 60 & 8 & - \\
\hline
\end{tabular}

office rooms located at north and south facades of the URS building on the $3^{\text {rd }}$ floor (as shown in

Fig. 3) were taken as examples to investigate the influence of night ventilation on the reduction

of indoor temperature and cooling potential for three consecutive typical summer days (June $30^{\text {th }}$ to July $2^{\text {nd }}$ ). Details of two office rooms are shown Table 4. Two window patterns: always open and open during occupied time period only, were applied to both offices respectively.

Table 4: Specification of two office rooms

\begin{tabular}{llll}
\hline $\begin{array}{l}\text { Office } \\
\text { room }\end{array}$ & Length $(\mathbf{m}) \times$ Width $(\mathbf{m}) \times$ & Glazing area $\left(\mathbf{m}^{2}\right)$ & Openable area \\
& Height $(\mathbf{m})$ & & \\
\hline North & $5.5 \times 4.8 \times 3.5$ & 5.46 & $20 \%$ \\
South & $4.8 \times 3.7 \times 3.5$ & 5.46 & $20 \%$ \\
\hline
\end{tabular}

\section{Results and discussions}

\subsection{Local climate characteristics}

Temperature is one of the most important climate factors that directly affect a building's

heating and cooling demands. Fig. 4a presents the monthly average dry-bulb temperature for six cases in the order of the month instead of the actual time for better presentation. Since the URS building is located on the campus of the University of Reading, which is on the outskirts of Reading, it was expected that there would not be a significant UHI for the measurement stations when compared with TMY, especially for the relatively large open area (MS1). When looking at the temperature differences between measurement stations and TMY (Fig. 4b), it is observed 
241

that the temperatures for all measurement stations are still higher than TMY for most months. Annual average temperature differences for station $1,2,3,4$ and AMY are $0.27{ }^{\circ} \mathrm{C}, 0.45^{\circ} \mathrm{C}$, $0.48^{\circ} \mathrm{C}, 0.73^{\circ} \mathrm{C}$ and $0.47^{\circ} \mathrm{C}$ respectively when compared with TMY. These values are still lower than the annual UHI intensity in other cities, such as $1.76^{\circ} \mathrm{C}$ in Beijing, China [48]; $1.0^{\circ} \mathrm{C}-1.1^{\circ} \mathrm{C}$ in Buenos Aires, Argentina [49]; and $2.4^{\circ} \mathrm{C}$ in Glasgow, UK [50].

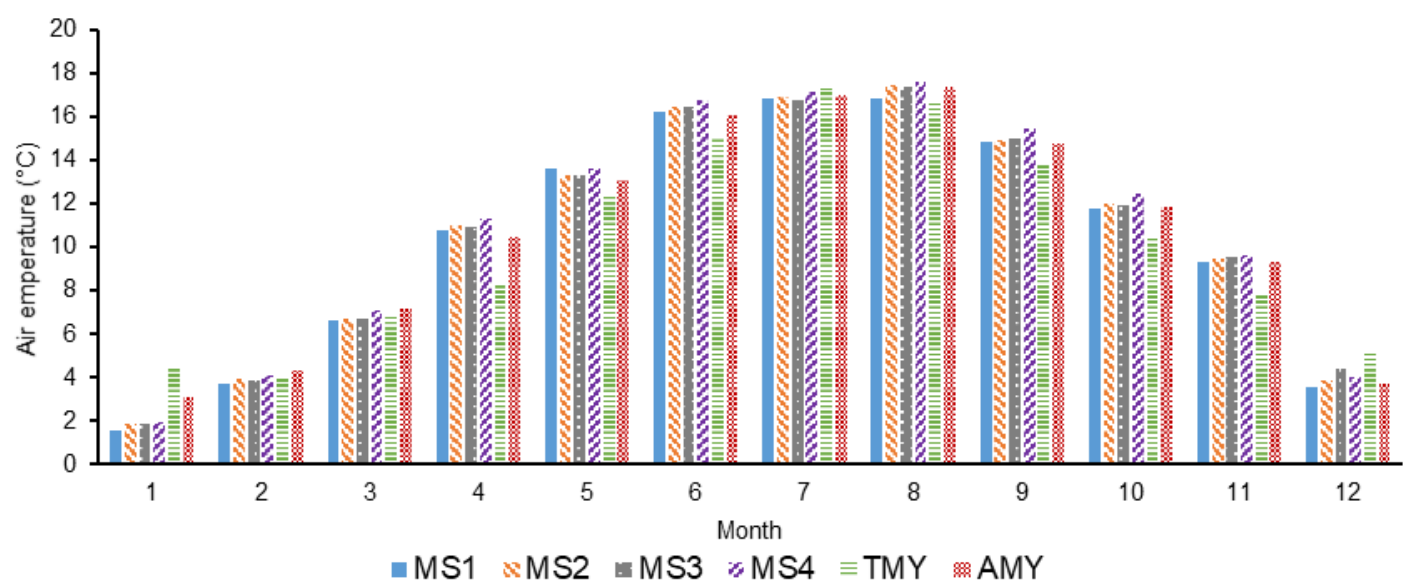

(a) Monthly average air temperature

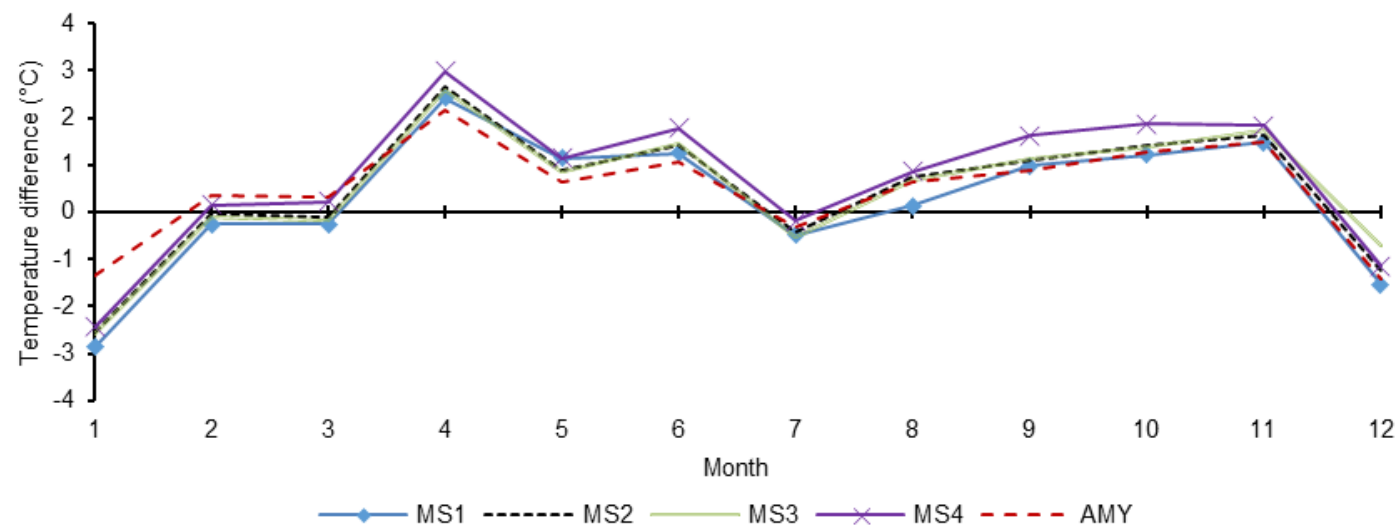

(b) Temperature difference between local measurements and TMY

Fig. 4: Comparison of monthly air temperatures

To better understand the microclimate inside different built forms, $31^{\text {st }}$ January and $1^{\text {st }}$ July are selected as the typical cold winter and hot summer days to compare the diurnal variations of air temperature, global solar radiation and win speed, as shown in Fig. 5 and Fig. 6. Considering the radiation and convection heat transfer could be major reason of temperature change, the 
solar radiation and the wind speed are mainly discussed. As shown in Fig. 5, on the summer day, the street canyon (MS2) and the courtyard (MS4) show the smaller diurnal temperature change range, both are $10.9{ }^{\circ} \mathrm{C}$. While in the less protective built forms, the diurnal change is $11.8{ }^{\circ} \mathrm{C}$ in the relatively open green area (MS1) and $12.1{ }^{\circ} \mathrm{C}$ in the semi-closed courtyard (MS3). This displays two opposite effects of the protective built forms: 1) the trapping of longwave radiation could increase the night temperature, while the shading effect could reduce the daytime temperature [51]. The solar radiation in the street canyon (MS2) was significantly lower than other built forms, which shows the impact of shading effect. During the whole day, the dominant background wind direction was east-northeast (ENE). Thus, the wind speed in the E-W street canyon became the highest. This results in a higher convection heat loss and a lower temperature comparing with the courtyard (MS4). In the courtyard (MS4), the solar radiation blocking is not so notable as it in the street canyon (MS2). This could be a result of the lower aspect ratio (0.38) comparing with it (0.60) in the street canyon (MS2). According to Fig. 6, during winter the air temperature in the street canyon (MS2) still displays a smaller changing range $\left(6.3^{\circ} \mathrm{C}\right)$, but peak temperature in the courtyard (MS4) becomes the highest during daytime. This could be a result of the high solar radiation, which was linked with the low aspect ratio, and the very low wind speed that reduced the convection cooling. Similar reasons also apply to the semi-closed courtyard (MS3). The solar radiation in winter also shows the effect of surrounding building locations and aspect ratio on the built form, as both of the semi-closed courtyard (MS3) and the courtyard (MS4) have low aspect ratio ( 0.20 and 0.38 respectively), while the street canyon (MS2) have higher aspect ratio (0.60). It is notable that although the aspect ratio of the open area is very small $(0.14)$, the solar radiation in the morning was lower than the semi-closed courtyard (MS3) and the courtyard (MS4), but in the afternoon the radiation became consistent with the semi-courtyard (MS3) as it was in summer. This could be a result of the high building block F located at the east of the open area blocking the winter sunshine small solar angle. During this day the dominant background wind directions were west 
276 (W) and west-southwest (WSW), which again resulted in higher wind speed inside the E-W

277 street canyon (MS2). However, it still needs to be noted that the temperature change inside built forms is a complex process that can be affected by a variety of potential factors apart from measured parameters. For example, vegetations could have cooling effect including the evapotranspiration and shading [52], and this is expected to have the most significant impact on the large open space (MS1). Also, because this study is based on the on-site monitoring in real building complex, some variables like distances between the monitoring station and surrounding buildings are difficult to control. This may also influence the solar radiation and wind patterns.

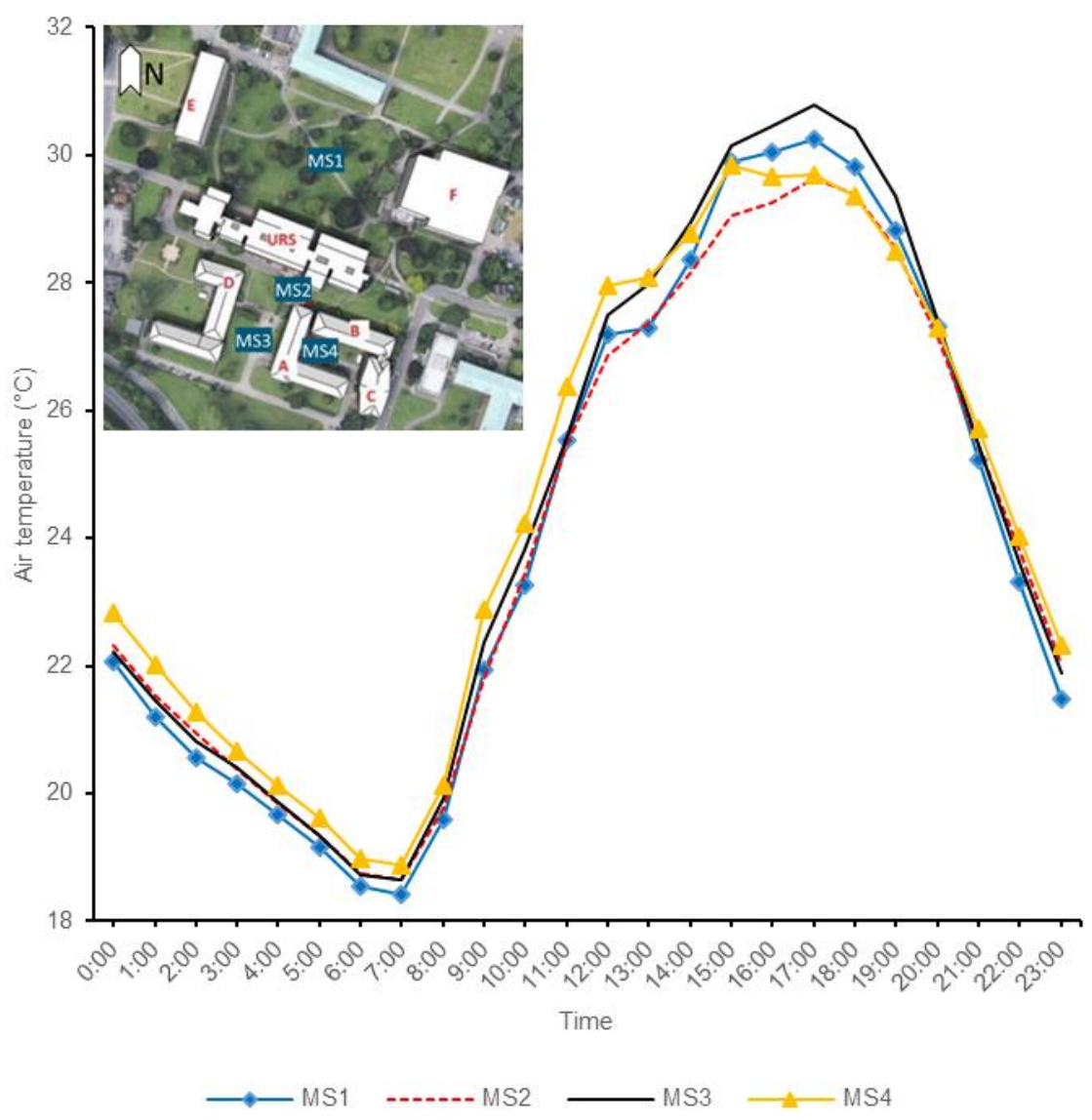

(a) Air temperature 


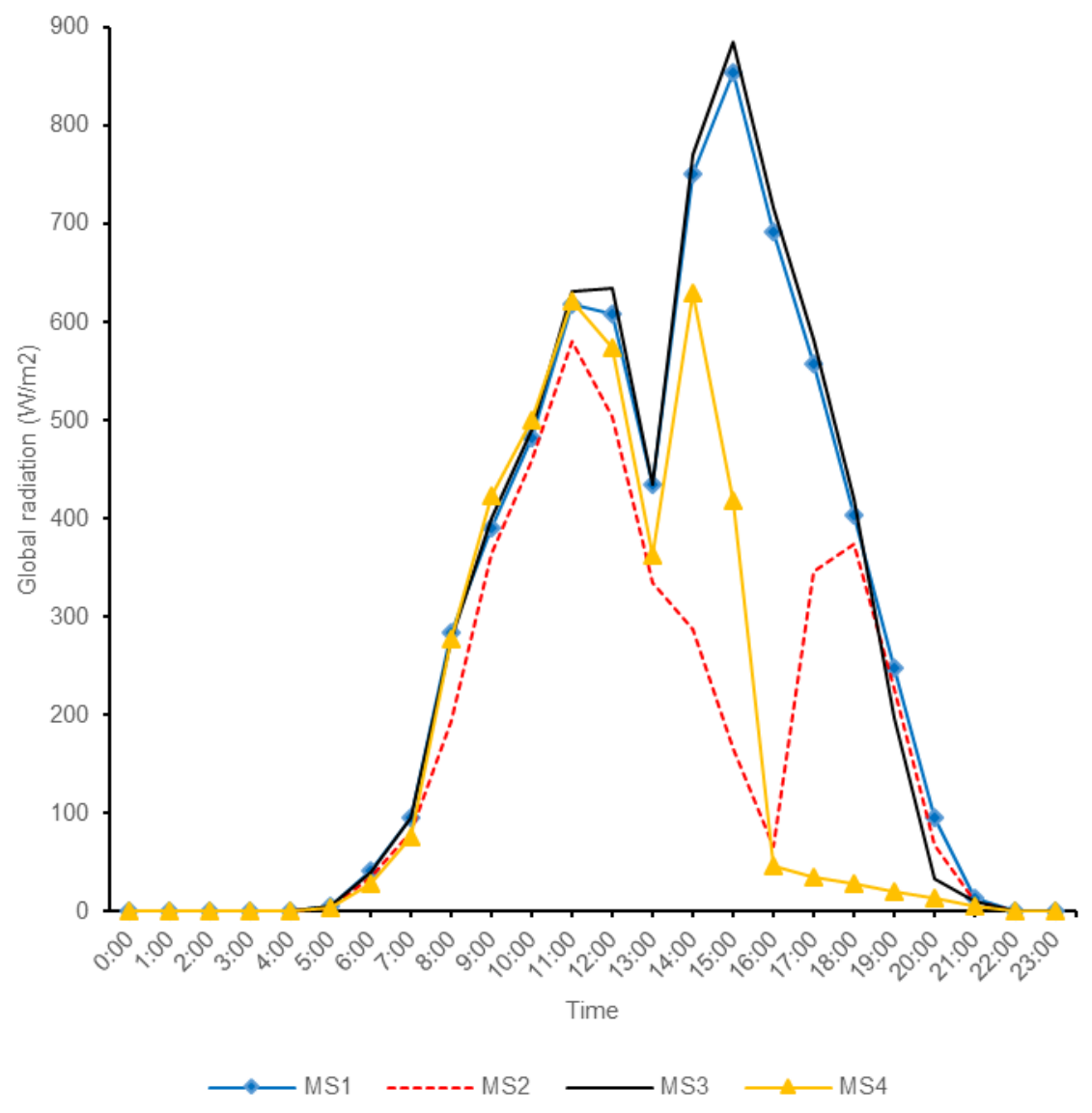

(b) Global solar radiation 


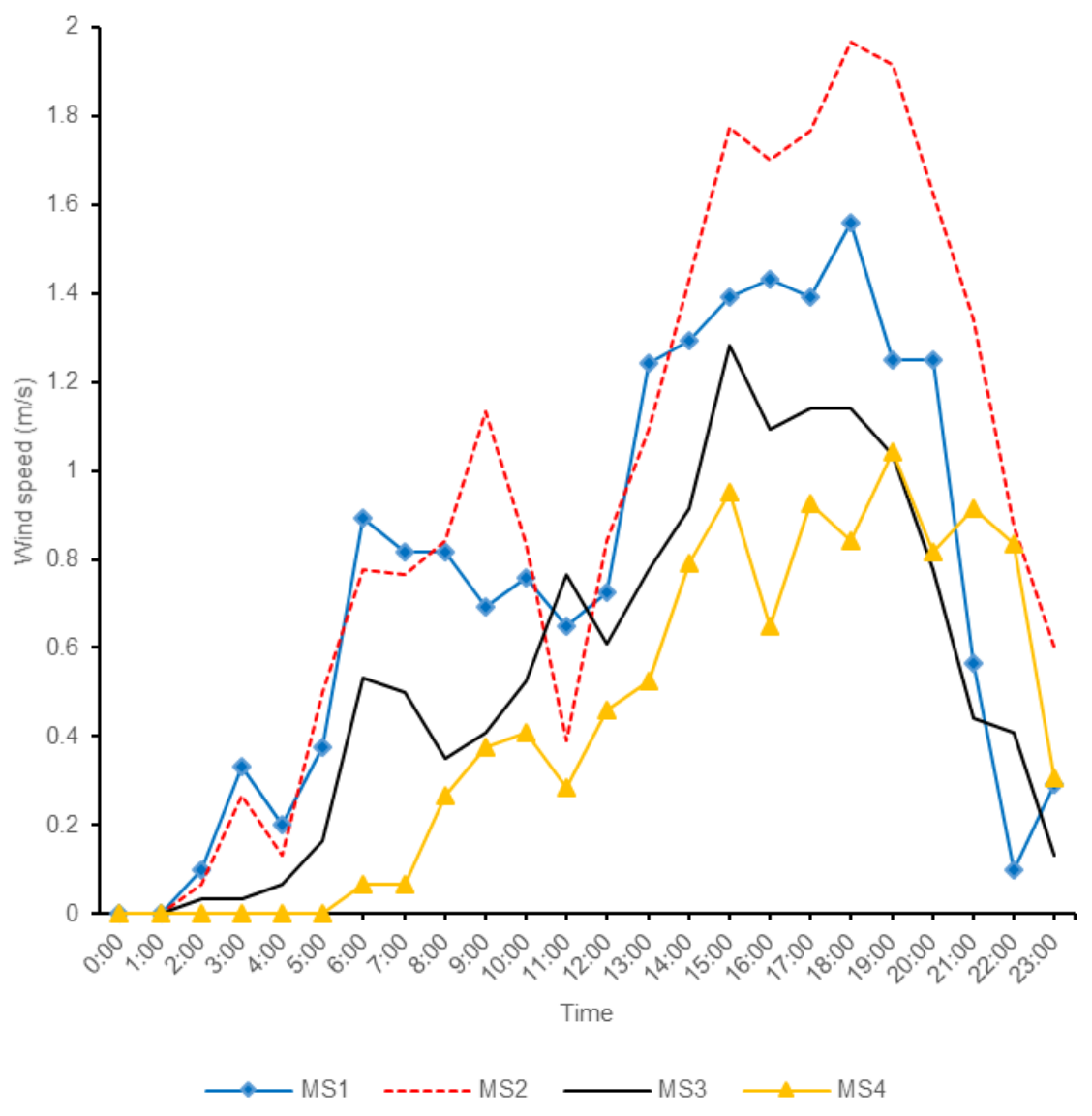

(c) Wind speed

291 Fig. 5: Diurnal variations of climate parameters in four built forms during a summer day ( $1^{\text {st }}$ July) 


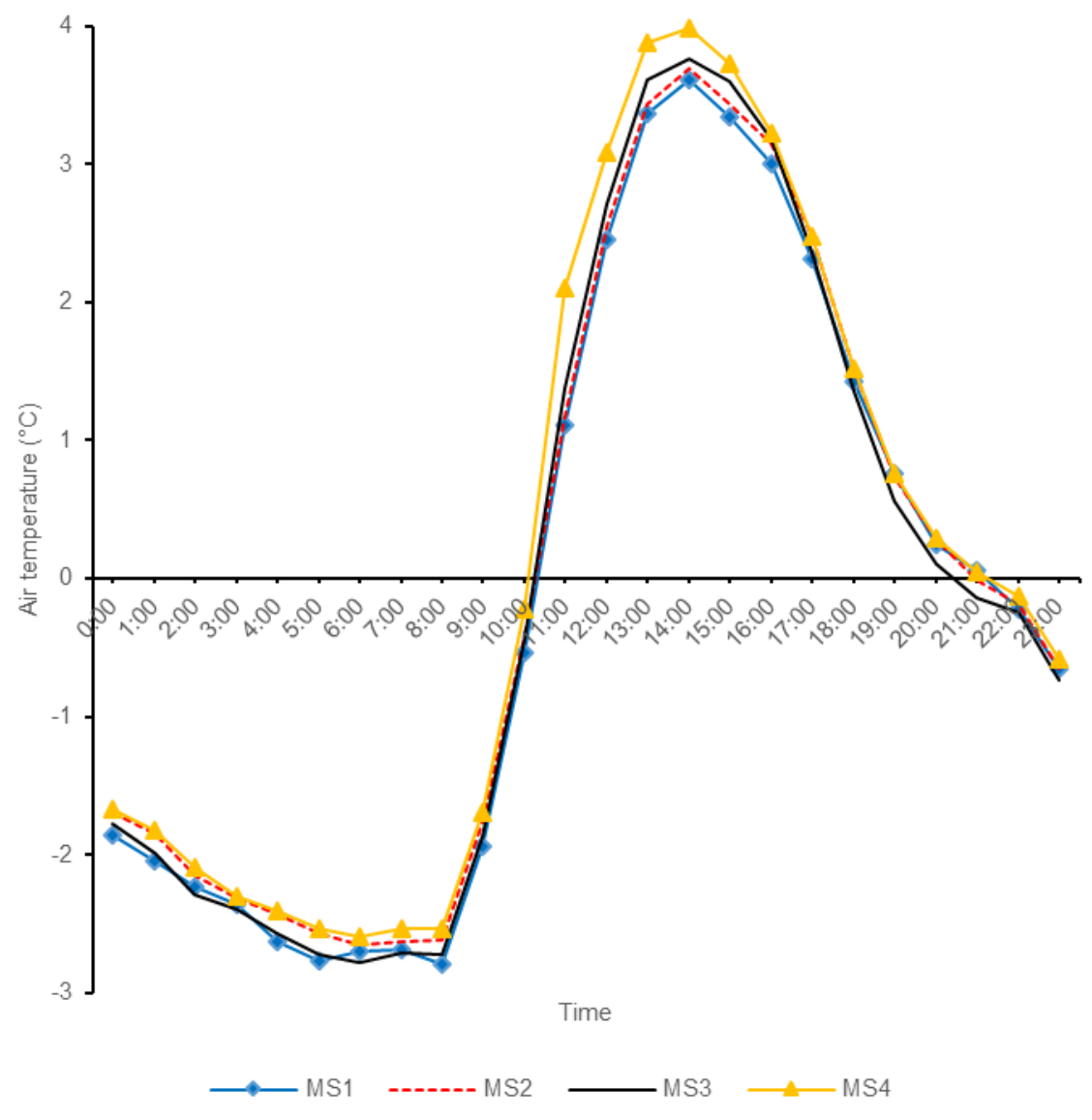

(a) Air temperature 


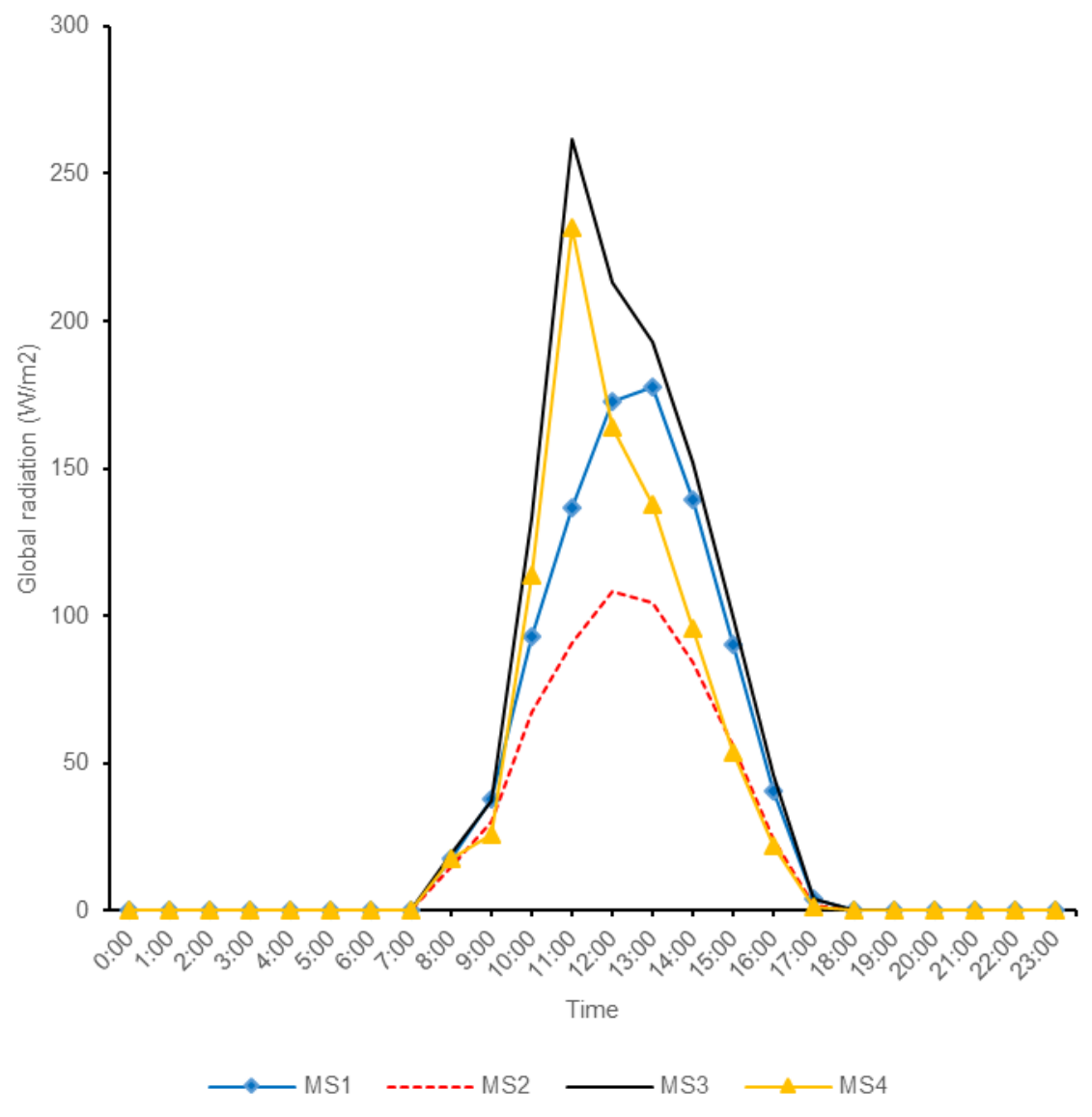

(b) Global solar radiation 


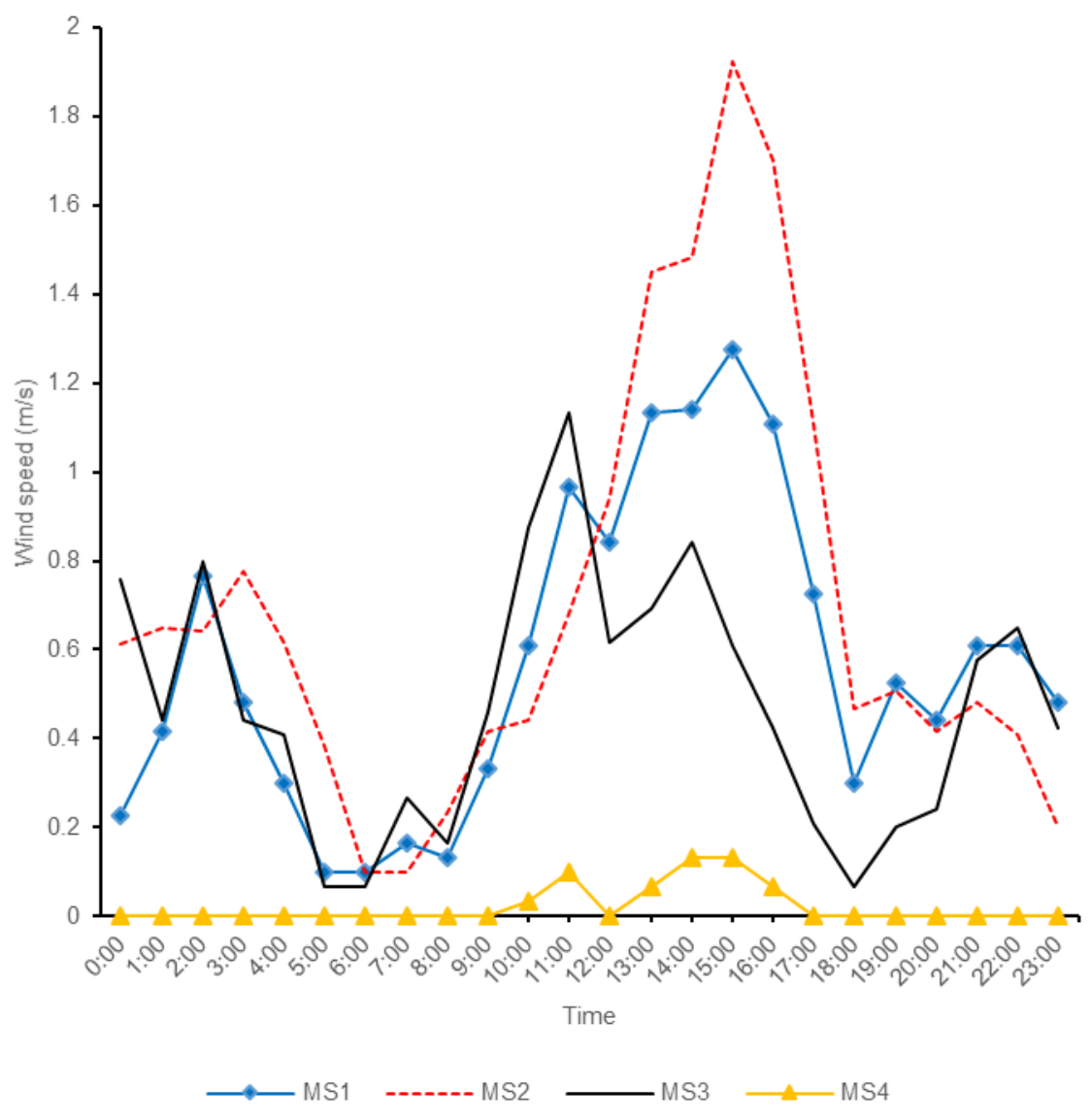

Fig. 6: Diurnal variations of climate parameters in four built forms during a winter day ( $31^{\text {st }}$ January)

The wind environment around the URS building was well studied by Gao et al. [53]. Their work mainly concentrated on establishing the correlation between measured wind pattern and built form. A wind rose for each station is shown in Fig. 7. Compared with TMY and AMY, all local measurement stations show a reduced wind speed and much changed wind direction. The wind rose for the large open area (MS1) shows the frequency of dominant wind directions, which are mainly from the spaces between nearby buildings in the west (W), southeast (SE) and northeast $(\mathrm{NE})$. As for the street canyon (MS2), the wind direction is mainly limited to west (W) and east (E) as a result of the blocking effect of building A and the URS building which form the canyon. For semi-closed courtyard (MS3) at the south side of the URS building, the dominant wind direction is from the southwest (SW), which matches the local dominant wind direction and the nearby 
building layouts. And for the courtyard (MS4), the wind speed is lower than other stations due to the shielding of the courtyard form, and the wind direction is northeast (NE) since the station was located at the southwest corner of the courtyard. The wind speed result is consistent with the study of Taleghani et al. [54] that highlights the most protected microclimate .

MS1

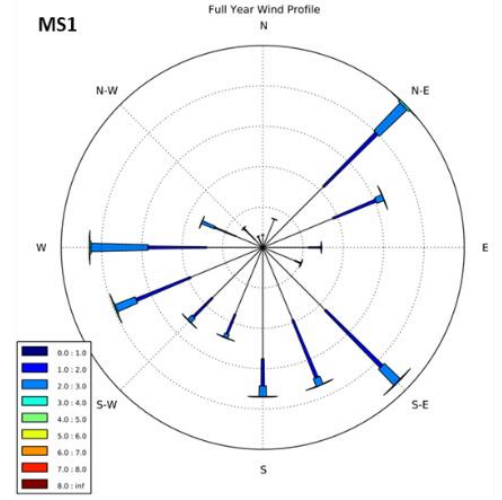

Ms4

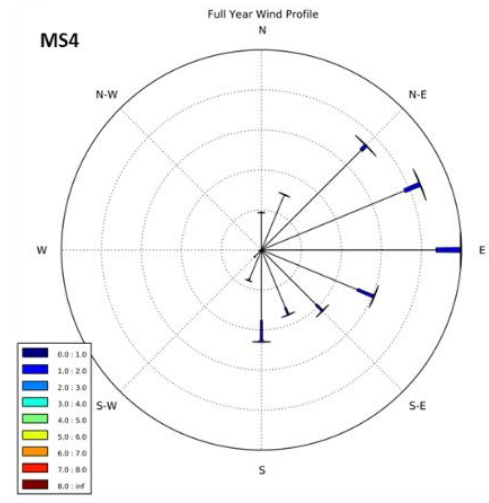

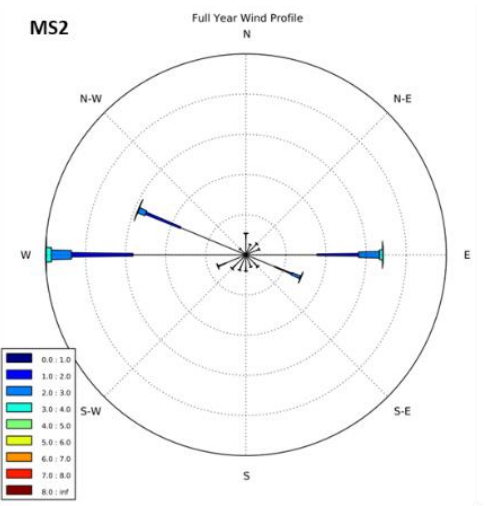

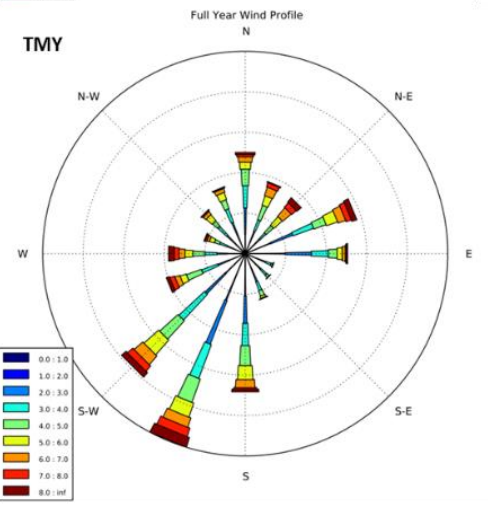

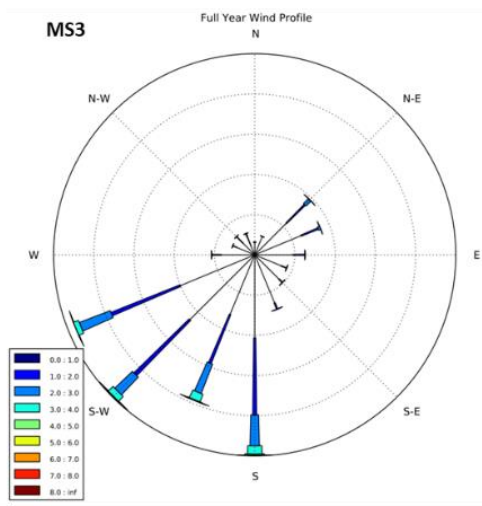

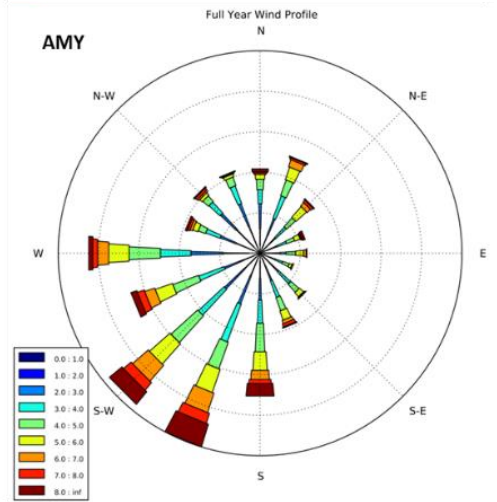

Fig. 7: Annual wind roses showing the wind direction and speed distribution for six types of weather data.

\subsection{Building heating load}

The building energy performance was simulated via IES-Apache. The simulated result is the room heating plant sensible load in kW, which is further converted into gas consumption in $\mathrm{kWh}$ by assuming an $80 \%$ efficiency of the heating plant in order to be comparable to the most available gas consumption data. The calculated monthly energy consumptions are shown in Fig. 
8, with a comparison with the actual gas meter record of the URS building in 2016 for validation.

As the gas was not metered before 2016, this is the best available data we can obtain. It is assumed that the gas consumption did not change over the years before 2016 as there is no change of function of the building and the occupancy remain largely unchanged. As can be observed, the meter record is significantly higher in March, April, October and December - and also slightly higher in the warm months (from May to September). This could be a result from the annual climate difference between 2016 and 2009/2010. Considering the low value of heating demand during warm months, this part of the data will be excluded from the following analysis of heating demand.

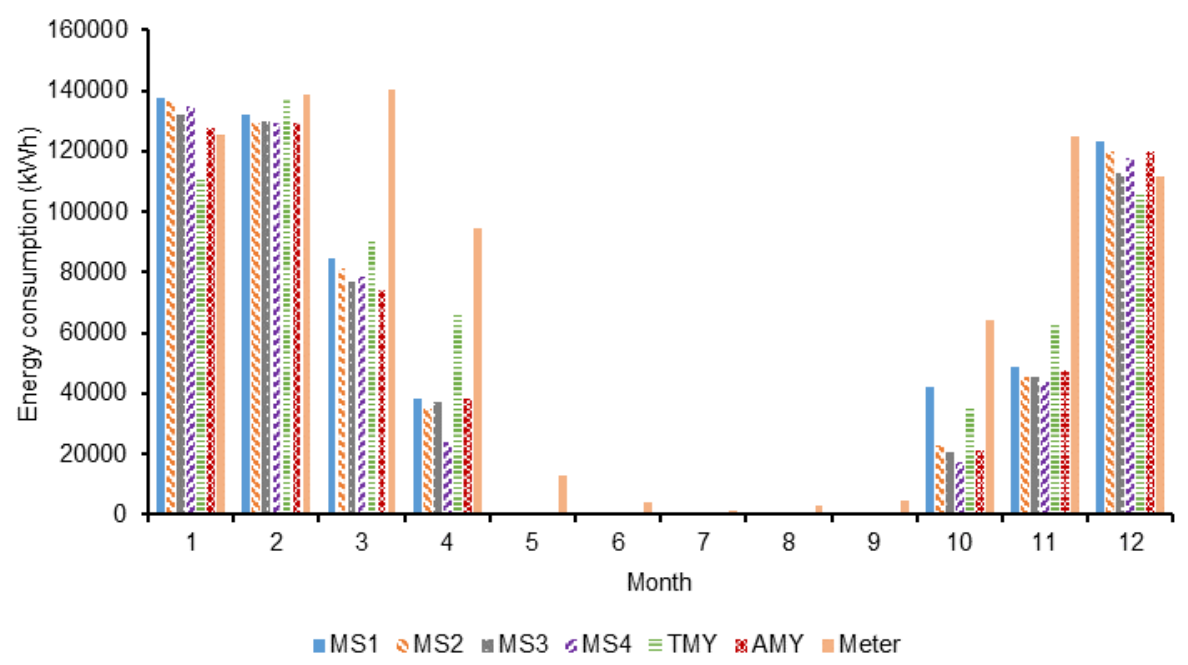

Fig. 8: Comparison between simulated energy consumption and actual meter records.

$$
\text { Percentage differences of heating demand during non-warm months are calculated }
$$
comparing with the meter value (Fig. 9). It shows that the difference between simulated results with 2009/2010 data is still large comparing with 2016 meter records. In the simulation, the solar radiation data used for four on-site measurements are all from TMY data because only global radiation was monitored and cannot be used as input. Thus the simulated results of heating demand are still largely based on the temperature difference and wind pattern. Higher air temperatures in the courtyard (MS4) and semi-closed courtyard (MS3) result from effects of 
higher solar radiation and lower wind speed lead to smaller heating demand. This result agrees well with various studies [26,55]. Heating demand of the street canyon (MS2) is slightly higher than it of the semi-closed courtyard (MS3), but still lower than it of the large open area (MS1) and TMY. The annual heating load reduction comparing local measurements and TMY is from $0.9 \%$ to $10.8 \%$ if taking TMY as the denominator, or from $0.6 \%$ (MS1) to $7.9 \%$ (MS4) if taking the meter value as the denominator. This is still lower than other cities, e.g. 12-16\% in Milan, Italy [11], 16\% in Beijing, China [10] and 11\% in Rome, Italy [7], as the university campus is located on the outskirts of the town of Reading. While the annual heating load reduction comparing local measurements and AMY is from $-5.6 \%(M S 1)$ or $1.4 \%(M S 2)$ to $1.6 \%(M S 4)$ if taking the meter value as the denominator. Variation between different built forms could be as high as $7.3 \%$ (MS1 and MS4) when taking the meter value as the denominator. Overall speaking, when local measurements are not available, using TMY data for urban building heating demand simulation would potentially lead to underestimation, while the reanalysed AMY data could be a better choice.

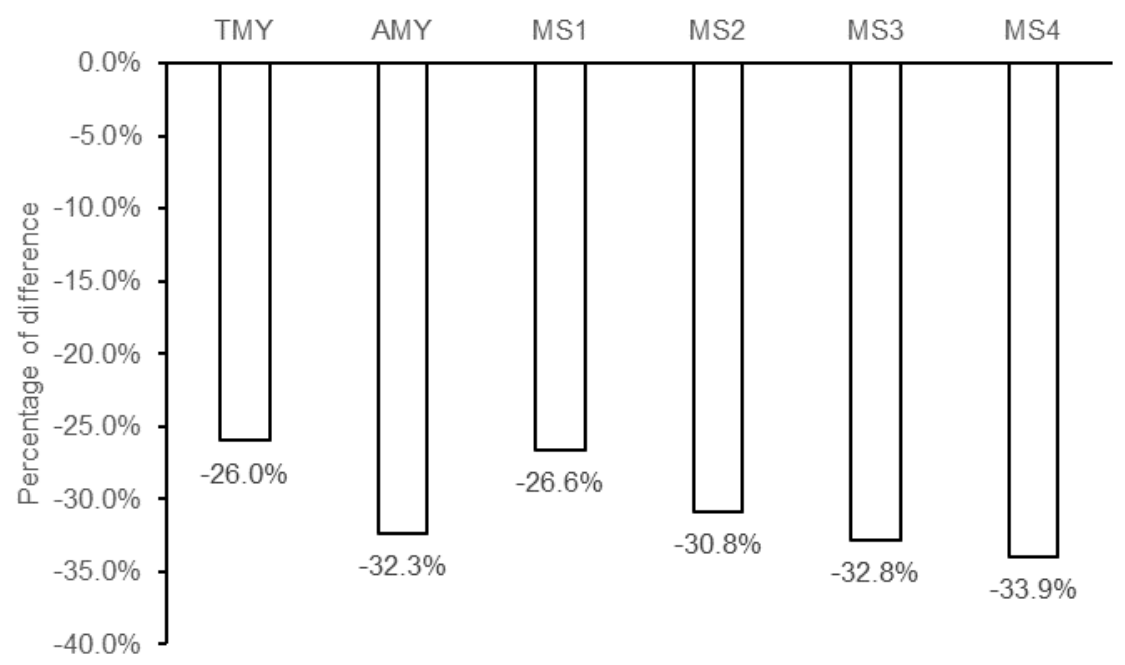

Fig. 9: Percentage differences for heating demand based on meter records 
To further understand the impact of the local climate on the natural ventilation cooling potential for the URS building in summer, two office rooms on the north and south façades of the building are chosen for analysis. The characteristics of night ventilation cooling for the two offices were simulated for four typical summer days (July $1^{\text {st }}$ to July $4^{\text {th }}$ ). Considering the simulation alignment, the first simulated day is excluded from the analysis. Hourly ventilation characteristics using MS1 as input data are shown in Fig. 10. Both only-daytime ventilation and all-day ventilation (daytime and night-time ventilation) are considered. Fig. 10 $\mathbf{c}$ and $\mathbf{d}$ show that the $\mathrm{ACH}$ and ventilation heat loss rate of the south office are continuously higher than them of the north office. This leads to lower indoor air temperatures of the south office especially at night, although the south office should receive more solar radiation than the north office in the daytime. For both rooms, the changing patterns of ventilation rates (Fig. 10c) are quite consistent during daytime (9:00 - 18:00) when windows are all open. While at night, night ventilation could reduce the indoor temperature significantly. The temperature difference (night ventilation versus day ventilation only) in the south office could reach up to $6.0^{\circ} \mathrm{C}$ at 5:00 on July $2^{\text {nd }}$, and then reduces to $3.6^{\circ} \mathrm{C}$ at 9:00 AM when working hours begin. The temperature difference decreases continuously along with the working time as a result of internal gains of people, lighting and other equipment. By the end of the working hours (18:00), the temperature difference is negligible. On July $3^{\text {rd }}$, as outdoor temperature decreases, the ventilation heat loss rate increases significantly, and reaches the peak value $47.1 \mathrm{~W} / \mathrm{m}^{2}$ in the south office with daytime-only ventilation, much larger than that on the previous day $\left(27.7 \mathrm{~W} / \mathrm{m}^{2}\right)$. The indoor temperature is higher than outdoor temperature during the period investigated for all cases, leading to a consistent positive ventilation cooling potential throughout the three typical summer days. 


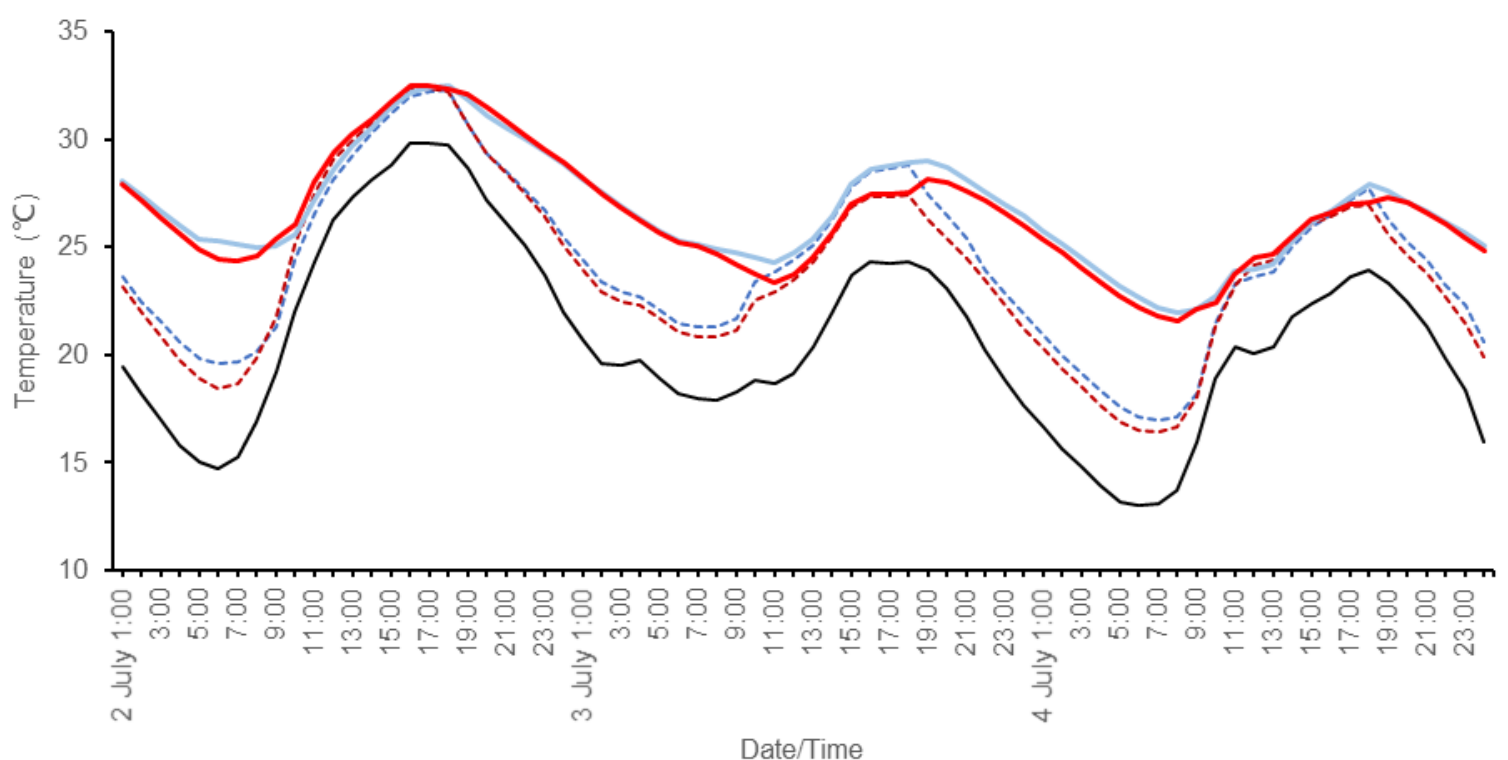

(a) Indoor and outdoor temperature

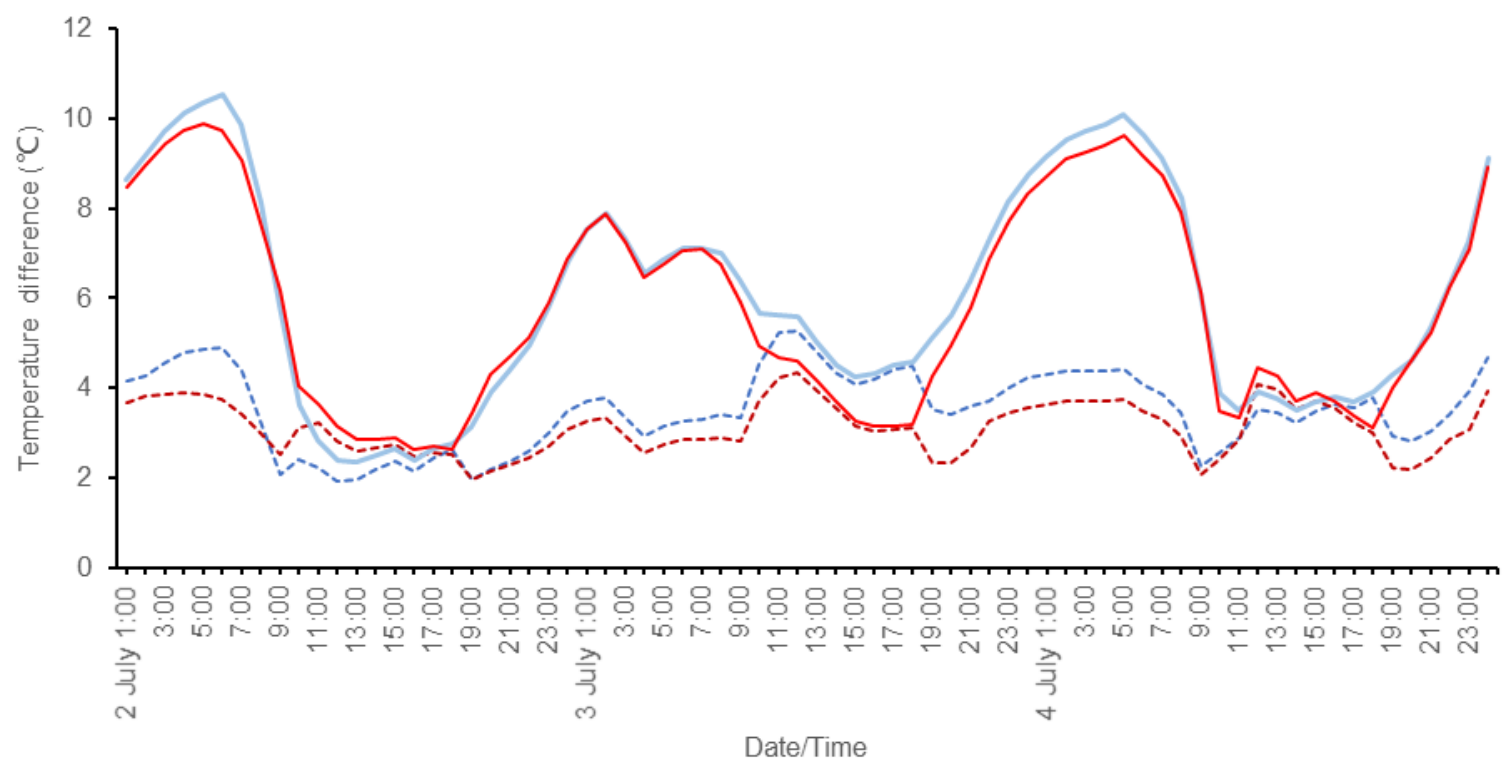

(b) Indoor-outdoor temperature difference 


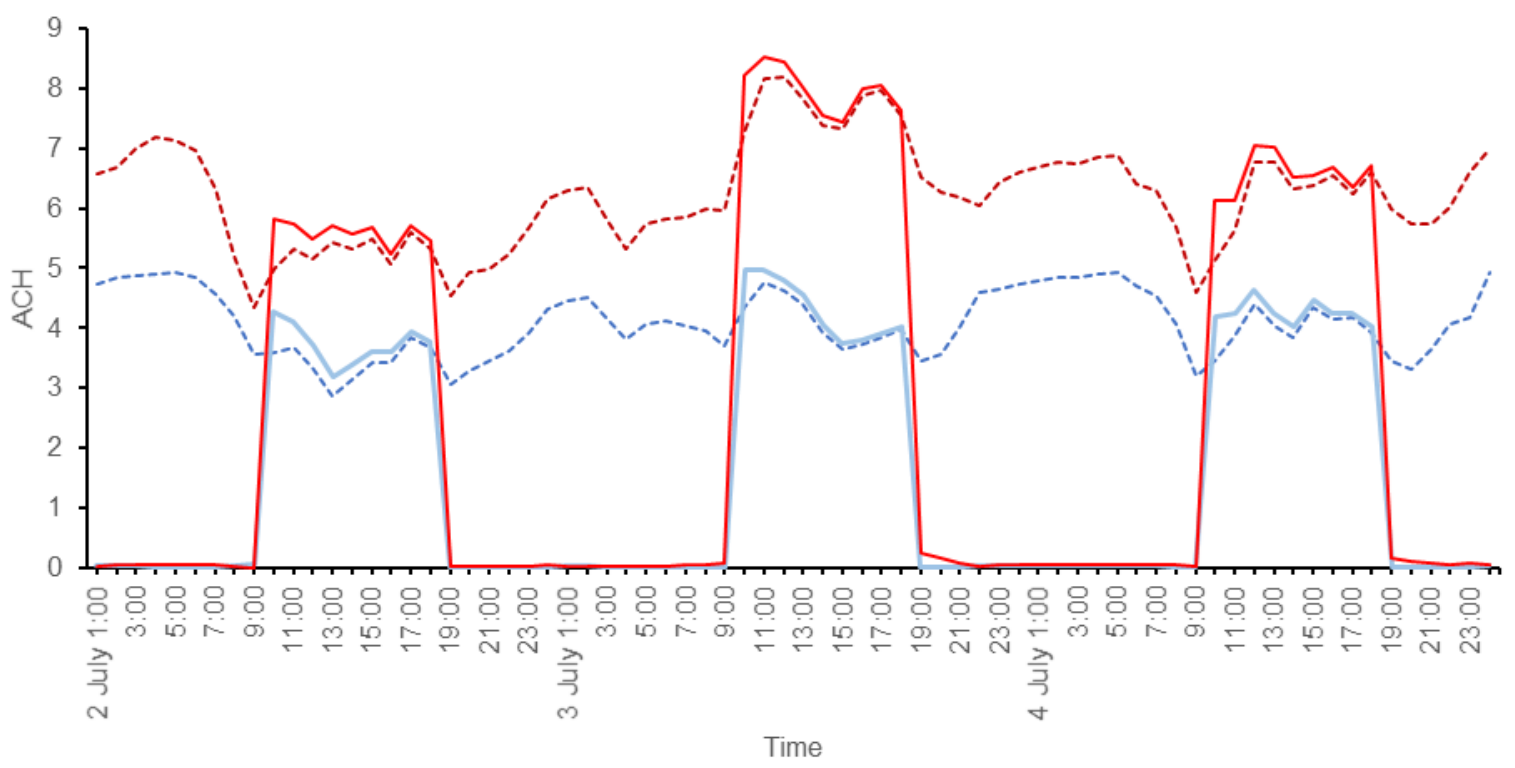

(c) Air changes per hour

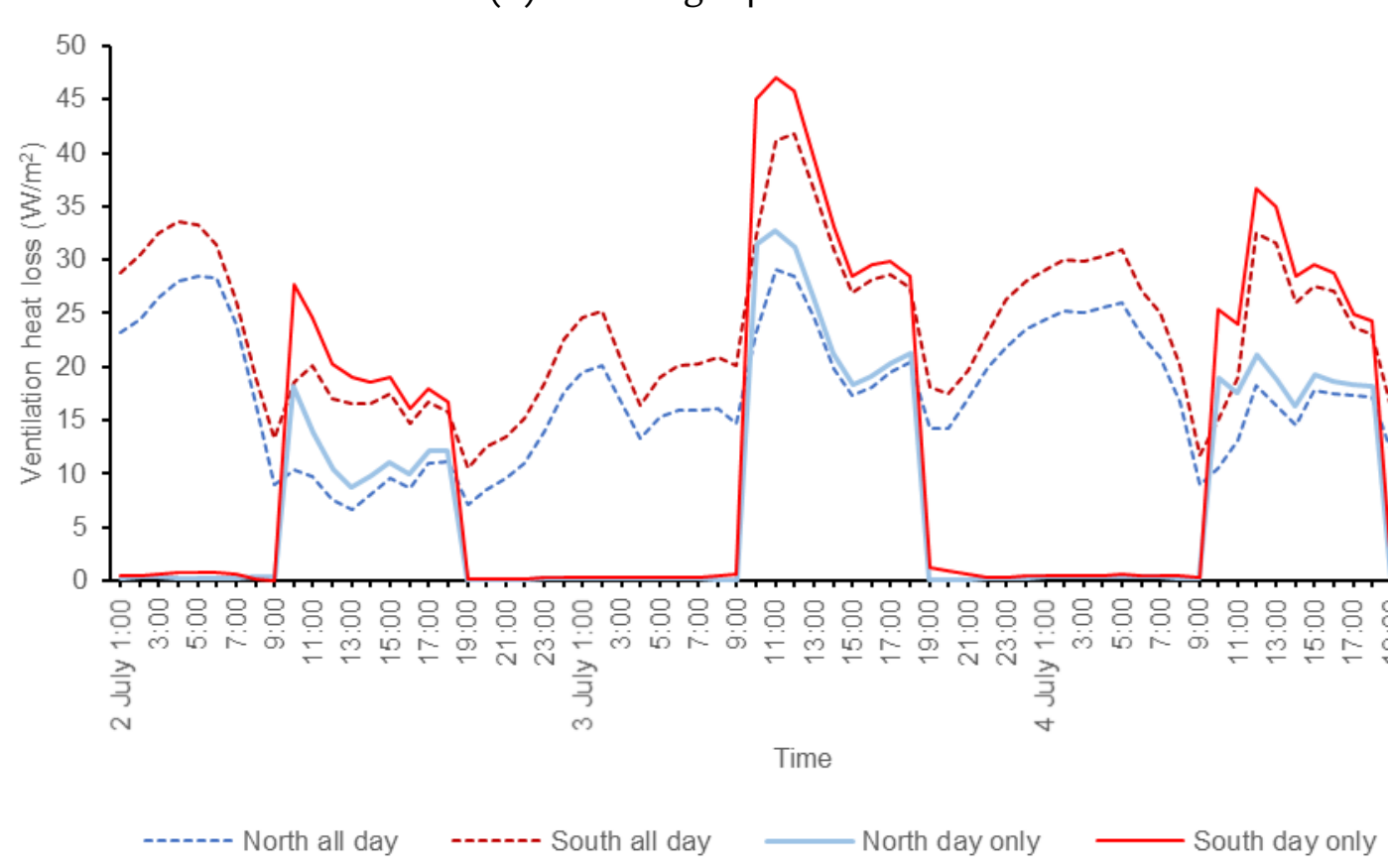

(d) Ventilation heat loss rate per unit area

Fig. 10: Passive ventilation cooling characteristics of the two offices with all-day (both day and night) and day-only ventilation from July $2^{\text {nd }}$ to $4^{\text {th }}$ using MS1 data The ventilation characteristics when using all weather data sources during the same three days (July $2^{\text {nd }}$ to $4^{\text {th }}$ ) are shown in Fig. 11. As terrain type was not set during the simulation, 
wind speeds of TMY and AMY are significantly higher than local measurements and resulted in higher air change rates. When considering local measurements only, the range of $\mathrm{ACH}$ for north office is between 2.8 and 5.3, while for south office it is between 4.2 and 8.4. According to CIBSE Guide A [38], the ventilation rate is recommended to be no less than $8 \mathrm{~L} / \mathrm{s}$ per person for office room. Considering the occupancy density $10 \mathrm{~m}^{2} /$ person, 2 people are assumed in both office rooms. Then the minimum criteria of ventilation for the north room is $0.62 \mathrm{ACH}$ and for the south room is $0.93 \mathrm{ACH}$. Thus, natural ventilation could meet minimum requirements. Comparing with TMY and AMY, the difference in ACH among local measurements is relatively small as a result of lower wind speeds. However, the largest variation could be as high as 1.0 for the north office ( $17: 00$, July $\left.4^{\text {th }}\right)$ and 1.6 for the south office $\left(16: 00\right.$, July $\left.3^{\text {rd }}\right)$. When comparing $\mathrm{ACH}$ of north and south offices, results show that the changing patterns in both offices are opposite. This difference highlights the changes in the surface-average pressure coefficient $\left(C_{p}\right)$ for natural ventilation due to variation of wind direction [56-58]. During the three days, wind direction in the semi-closed courtyard (MS3) remains the closest to the south, especially on the last two days, and this results in the highest $\mathrm{ACH}$ for the south office comparing with other built forms. Although the wind speed in the courtyard (MS4) remains the lowest among all built forms, on the third day the wind direction in the courtyard is the closest to the north, which rises the $\mathrm{ACH}$ for the north office. This indicates that the variation in the $\mathrm{ACH}$ of different built forms is largely influenced by not only the wind speed but also the wind direction. 


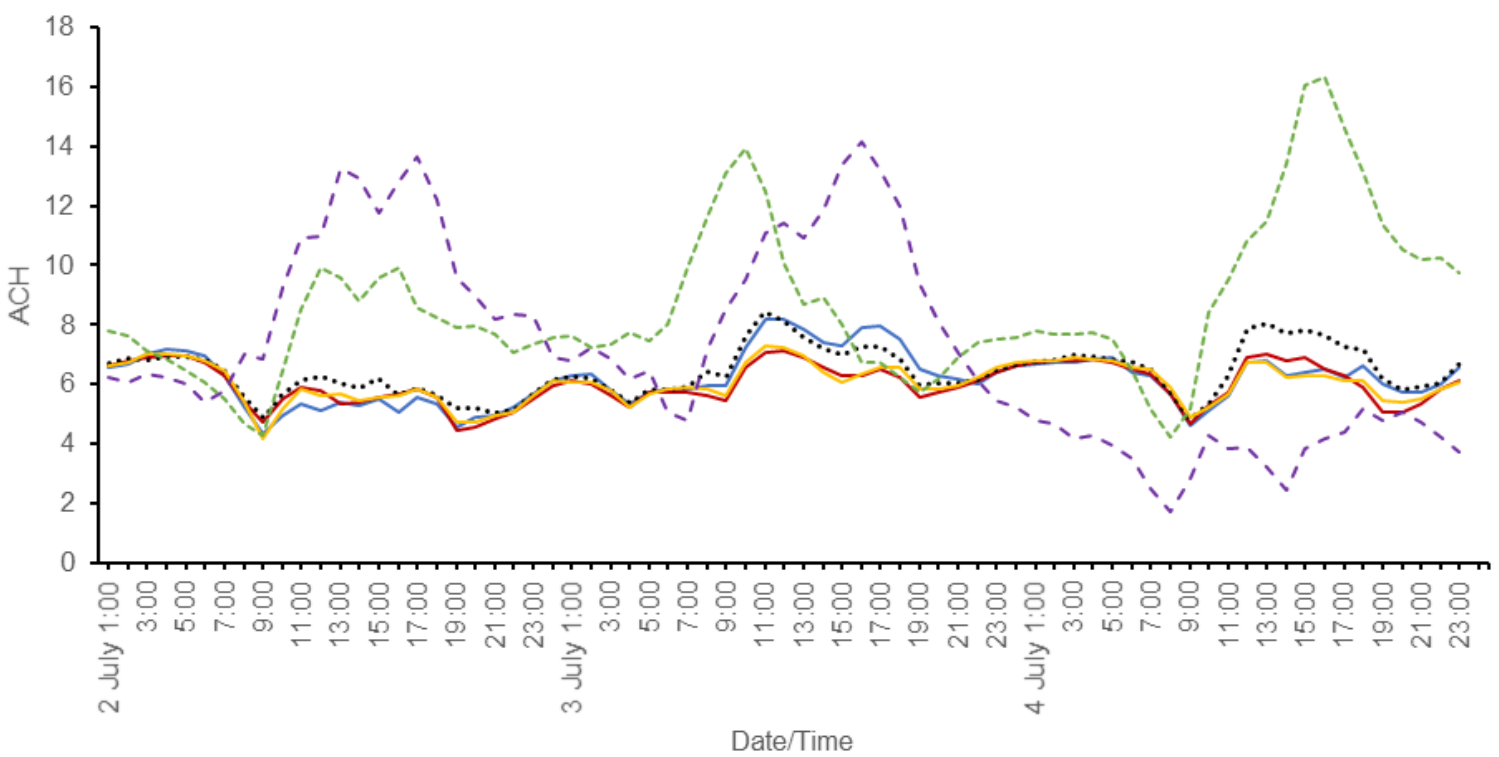

(a) $\mathrm{ACH}$ of the south office

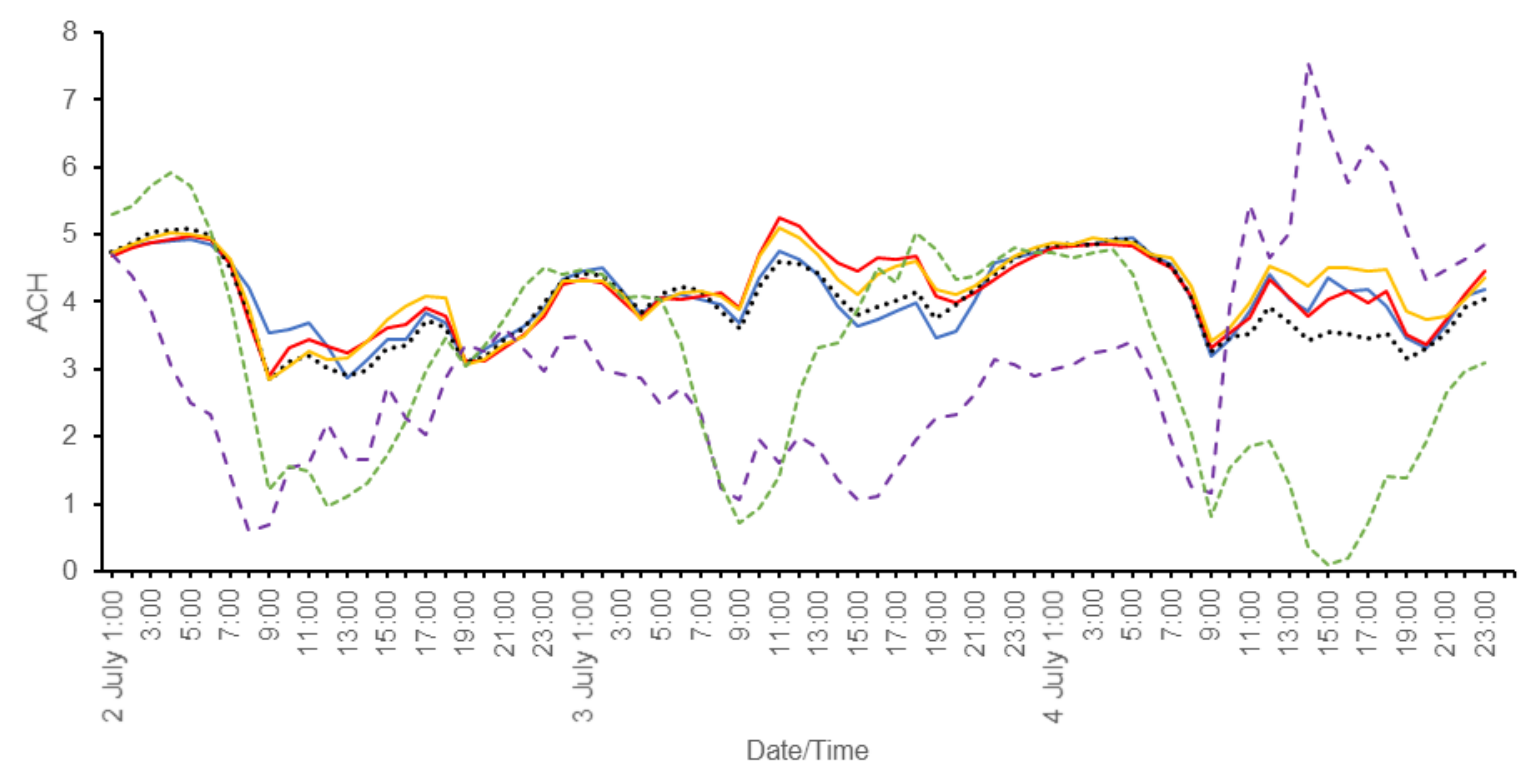

(b) $\mathrm{ACH}$ of the north office 


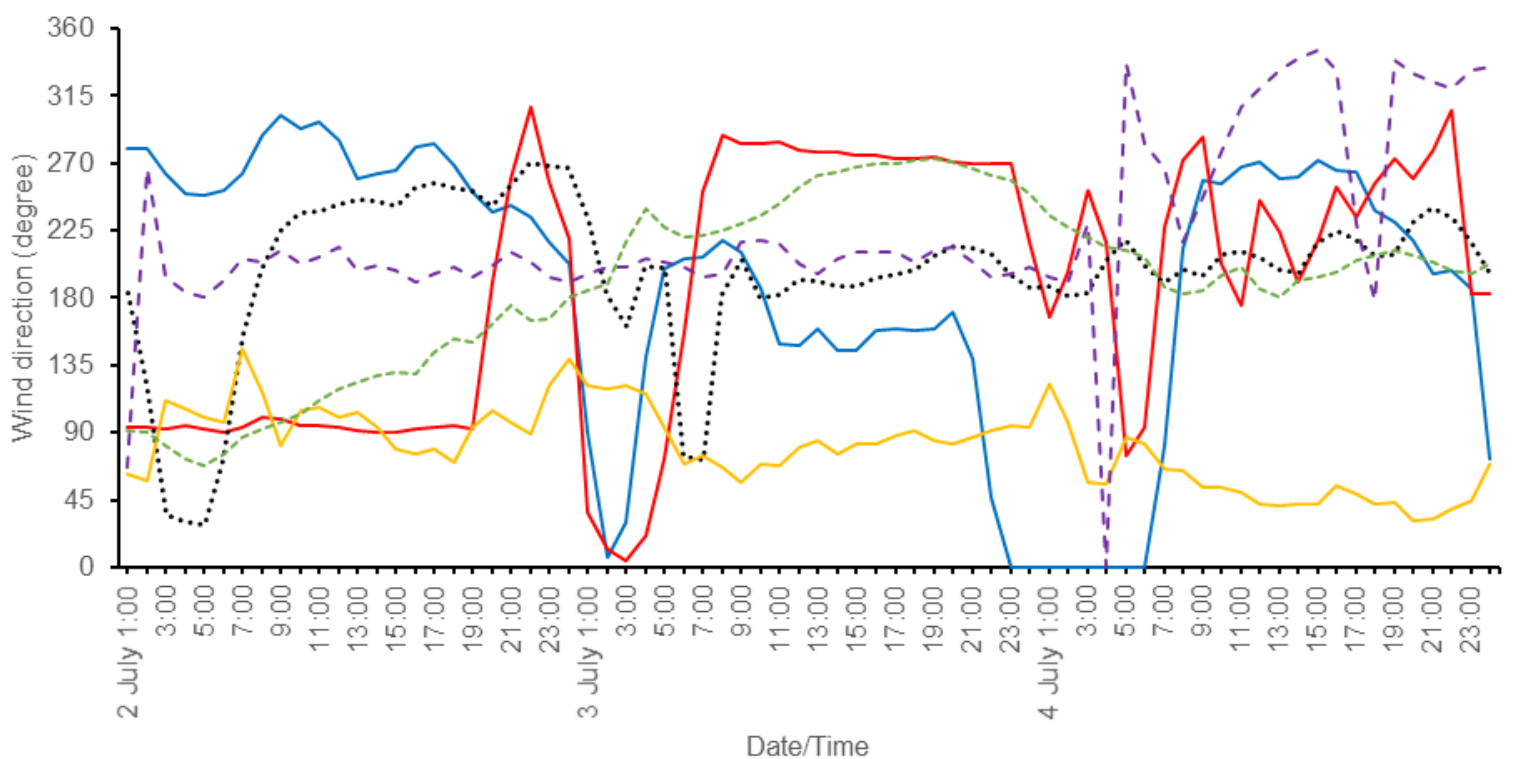

(c) Site wind direction

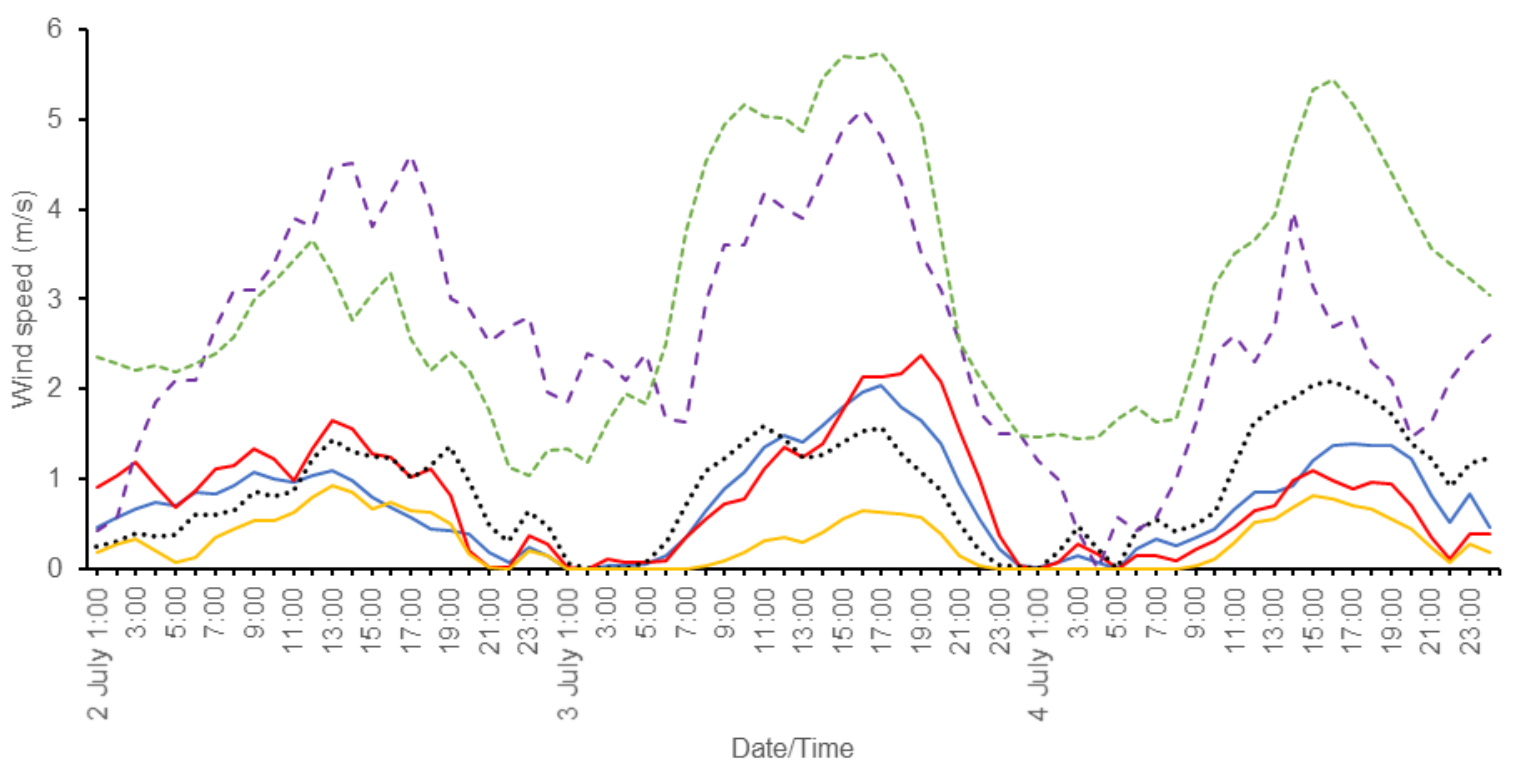

(d) Site wind speed

Fig. 11: Ventilation characteristics of the south and north office with night ventilation during 
427 difference between cases with and without night ventilation during the three summer days. This

428 shows that night ventilation could effectively cool down the room for at least $2.3^{\circ} \mathrm{C}$ in average when considering local measurements only. It is seen that for both north and south offices, the temperature reduction of AMY is larger and it of TMY is smaller. Percentage differences in ventilation heat loss rate (both south and north offices) for all weather data sources comparing with TMY are shown in Fig. 12b. Both figures indicate that using TMY would underestimate the night ventilation cooling potential comparing with local climate data, with percentages of 41 $47 \%$ for the north office and $14-17 \%$ for the south office in terms of heat loss rate. Using AMY would overestimate the heat loss rate by $29-32 \%$ for the south office and $9-15 \%$, for the north office. These differences in heat loss rate are largely related to the variation in $\mathrm{ACH}$, as shown in

Fig. 11a and $\mathbf{b}$. In comparison, differences between local measurements are relatively insignificant. It still can be seen that the courtyard (MS4) has the largest and the street canyon (MS2) has the smallest temperature drop among all built forms. Because of the high aspect ratio as analysed in previous sections, the street canyon (MS2) has the lowest ventilation heat loss rate with night ventilation.

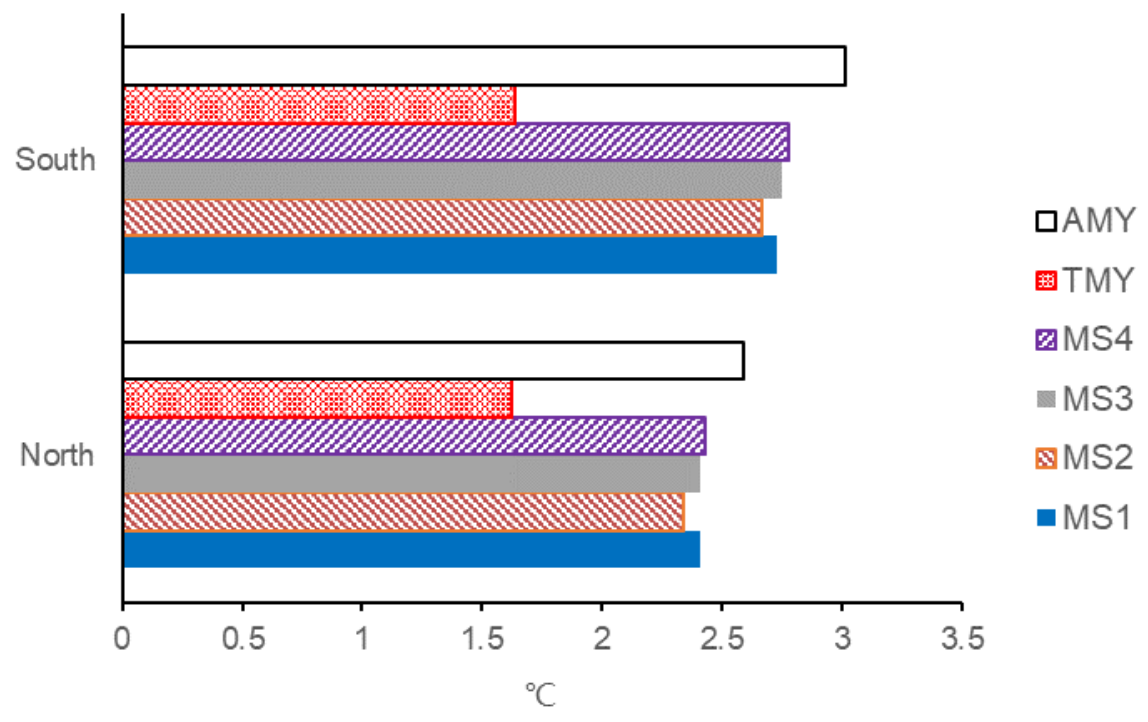




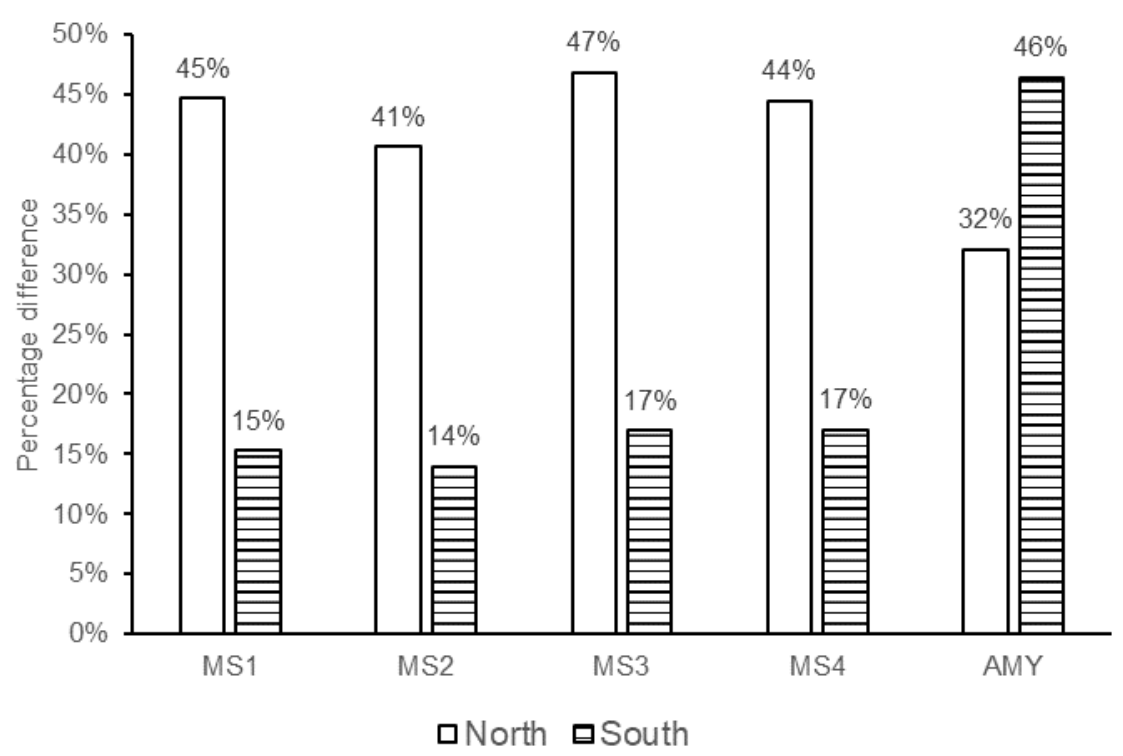

(b)

Fig. 12: (a) Average temperature difference between cases with/out night ventilation; (b) Percentage differences in ventilation heat loss rate (both south and north offices) of all weather data sources comparing with TMY of three summer days (July $2^{\text {nd }}$ to $4^{\text {th }}$ ).

In summary, night ventilation would help to cool the room down effectively during summertime. Although the difference among different local stations may not be as significant as comparing with typical weather files, the courtyard is shown to have the largest night ventilation cooling potential in reducing indoor air temperature and the second highest ventilation heat loss rate. The street canyon is shown to have the lowest night ventilation cooling potential. Using either TMY or AMY for simulation would potentially lead to uncertainty in night ventilation cooling potential estimation. It should be noted that the simulated small night ventilation cooling potential is not equal to the low cooling energy demand if air-conditioning system exists, as the courtyard with lower aspect ratio may still access more solar irradiation during the daytime and results in higher air temperature comparing with the street canyon with higher aspect ratio $[22,26,59]$. 
Although it is well-known that using TMY for building energy simulation would result in uncertainties, local measurements could also show distinctions because of various built forms in the neighbourhood. Impacts of different built forms on local microclimates and further on building performance in real-world circumstance are still not fully understood. In this study, a year-long measurement was conducted to demonstrate that neighbourhood-scale microclimates surrounding the same building would still show variations, which is due to the variation in solar radiation and wind patterns caused by different built form types and orientations. These differences in climate parameters would further influence the building heating demand and natural ventilation cooling potential.

In summer, effects of solar radiation shading during daytime and thermal trapping at night are observed in the street canyon and the courtyard. While in winter, built forms with lower aspect ratio will have higher temperature. The variation among different built forms is $7.3 \%$, where the large open area has the highest heating demand and the courtyard has the lowest heating demand. The uncertainty of using TMY for annual heating demand simulation could be as high as $10.8 \%$ when comparing with local measurements, while the uncertainty of using AMY is much smaller. During three typical summer days, the variation in ventilation heat loss is not very significant comparing with typical weather files, but it still could be found the courtyard and the semi-closed form have the higher night ventilation cooling potential than other built forms, while the street canyon has the lowest night ventilation cooling potential. Using TMY could underestimate the total night ventilation cooling rate (both north and south offices) by 26 - 31\% and using AMY could overestimate it by $9-14 \%$. Overall speaking, the courtyard has the lowest heating demand in winter, and relatively high natural ventilation cooling potential in summer. While the street canyon is the built form with relatively high heating demand in winter and the lowest night ventilation cooling potential in summer. validation; (2) Variables like the distance between measurement stations and surrounding buildings, aspect ratios and orientations of built forms cannot be unified; (3) Potential factors like vegetations 
501

502

503

504

that would have influences on environmental parameters were not taken into consideration. Future works are encouraged to have an in-depth look at the impact of more other built form types on local microclimate through both simulation and measurement approaches in other climates and countries.

\section{Acknowledgment}

Datasets used for this work were financially supported by EPSRC project (EPSRC EP/F039867/1).

\section{References}

[1] UK Green Building Council, Energy efficiency in the UK's buildings: key priorities for the new government, 2017. https://www.ukgbc.org/wp-content/uploads/2017/09/UK-GBCAldersgate-Energy-Efficiency-Briefing.pdf (accessed March 6, 2019).

[2] E.\& I.S. Department for Business, Energy consumption in the UK, (2018). https://assets.publishing.service.gov.uk/government/uploads/system/uploads/attachment _data/file/729317/Energy_Consumption_in_the_UK_ECUK__2018.pdf(accessed November 1, 2018).

[3] H. Yoshino, T. Hong, N. Nord, IEA EBC annex 53: Total energy use in buildings-Analysis and evaluation methods, Energy Build. 152 (2017) 124-136. doi:10.1016/j.enbuild.2017.07.038.

[4] M. Palme, L. Inostroza, G. Villacreses, A. Lobato-Cordero, C. Carrasco, From urban climate to energy consumption. Enhancing building performance simulation by including the urban heat island effect, Energy Build. 145 (2017) 107-120. doi:10.1016/j.enbuild.2017.03.069. 
508

509

510

511

512

513

514

515

516

517

518

519

520

521

522

523

524

525

526

527

528

529

[5] A. Gros, E. Bozonnet, C. Inard, M. Musy, Simulation tools to assess microclimate and building energy - A case study on the design of a new district, Energy Build. 114 (2016) 112-122. doi:10.1016/J.ENBUILD.2015.06.032.

[6] X. Li, Y. Zhou, S. Yu, G. Jia, H. Li, W. Li, Urban heat island impacts on building energy consumption: A review of approaches and findings, Energy. 174 (2019) 407-419. doi:10.1016/j.energy.2019.02.183.

[7] C. Guattari, L. Evangelisti, C.A. Balaras, On the assessment of urban heat island phenomenon and its effects on building energy performance: A case study of Rome (Italy), Energy Build. 158 (2018) 605-615. doi:10.1016/J.ENBUILD.2017.10.050.

[8] M. Zinzi, E. Carnielo, B. Mattoni, On the relation between urban climate and energy performance of buildings. A three-years experience in Rome, Italy, Appl. Energy. 221 (2018) 148-160. doi:10.1016/j.apenergy.2018.03.192.

[9] A. Afshari, A new model of urban cooling demand and heat island-application to vertical greenery systems (VGS), Energy Build. 157 (2017) 204-217. doi:10.1016/J.ENBUILD.2017.01.008.

[10] Y. Cui, D. Yan, T. Hong, J. Ma, Temporal and spatial characteristics of the urban heat island in Beijing and the impact on building design and energy performance, Energy. 130 (2017) 286-297. doi:10.1016/J.ENERGY.2017.04.053.

[11] R. Paolini, A. Zani, M. MeshkinKiya, V.L. Castaldo, A.L. Pisello, F. Antretter, T. Poli, F. Cotana, The hygrothermal performance of residential buildings at urban and rural sites: Sensible and latent energy loads and indoor environmental conditions, Energy Build. 152 (2017) 792-803. doi:10.1016/J.ENBUILD.2016.11.018. 
[12] A. Salvati, H. Coch Roura, C. Cecere, Assessing the urban heat island and its energy impact on residential buildings in Mediterranean climate: Barcelona case study, Energy Build. 146 (2017) 38-54. doi:10.1016/J.ENBUILD.2017.04.025.

[13] A. Chatzidimitriou, S. Yannas, Street canyon design and improvement potential for urban open spaces; the influence of canyon aspect ratio and orientation on microclimate and outdoor comfort, Sustain. Cities Soc. 33 (2017) 85-101. doi:10.1016/j.scs.2017.05.019.

[14] J. Allegrini, V. Dorer, J. Carmeliet, Influence of morphologies on the microclimate in urban neighbourhoods, J. Wind Eng. Ind. Aerodyn. 144 (2015) 108-117. doi:10.1016/j.jweia.2015.03.024.

[15] E. Andreou, Thermal comfort in outdoor spaces and urban canyon microclimate, Renew. Energy. 55 (2013) 182-188. doi:10.1016/j.renene.2012.12.040.

[16] F. Bourbia, F. Boucheriba, Impact of street design on urban microclimate for semi arid climate (Constantine), Renew. Energy. 35 (2010) 343-347. doi:10.1016/j.renene.2009.07.017.

[17] V.P. López-Cabeza, C. Galán-Marín, C. Rivera-Gómez, J. Roa-Fernández, Courtyard microclimate ENVI-met outputs deviation from the experimental data, Build. Environ. 144 (2018) 129-141. doi:10.1016/j.buildenv.2018.08.013.

[18] A. Forouzandeh, Numerical modeling validation for the microclimate thermal condition of semi-closed courtyard spaces between buildings, Sustain. Cities Soc. 36 (2018) 327345. doi:10.1016/j.scs.2017.07.025.

[19] J. Strømann-Andersen, P.A. Sattrup, The urban canyon and building energy use: Urban density versus daylight and passive solar gains, Energy Build. 43 (2011) 2011-2020. doi:10.1016/j.enbuild.2011.04.007. 
553 [20] J. Allegrini, V. Dorer, J. Carmeliet, Influence of the urban microclimate in street canyons on

554

555

556

557

558

559

560

561

562

563

564

565

566

567

568

569

570

571

572

573

574

575

576 the energy demand for space cooling and heating of buildings, Energy Build. 55 (2012) 823-832. doi:10.1016/J.ENBUILD.2012.10.013.

[21] C. Ratti, D. Raydan, K. Steemers, Building form and environmental performance: archetypes, analysis and an arid climate, Energy Build. 35 (2003) 49-59. doi:10.1016/S0378-7788(02)00079-8.

[22] A.S. Muhaisen, M.B. Gadi, Effect of courtyard proportions on solar heat gain and energy requirement in the temperate climate of Rome, Build. Environ. 41 (2006) 245-253. doi:10.1016/j.buildenv.2005.01.031.

[23] L. Shashua-Bar, M.E. Hoffman, Y. Tzamir, Integrated thermal effects of generic built forms and vegetation on the UCL microclimate, Build. Environ. 41 (2006) 343-354. doi:10.1016/j.buildenv.2005.01.032.

[24] V. Geros, M. Santamouris, S. Karatasou, A. Tsangrassoulis, N. Papanikolaou, On the cooling potential of night ventilation techniques in the urban environment, Energy Build. 37 (2005) 243-257. doi:10.1016/J.ENBUILD.2004.06.024.

[25] M. Santamouris, N. Papanikolaou, I. Livada, I. Koronakis, C. Georgakis, A. Argiriou, D.. Assimakopoulos, On the impact of urban climate on the energy consumption of buildings, Sol. Energy. 70 (2001) 201-216. doi:10.1016/S0038-092X(00)00095-5.

[26] Z. Zamani, S. Heidari, P. Hanachi, Reviewing the thermal and microclimatic function of courtyards, Renew. Sustain. Energy Rev. 93 (2018) 580-595. doi:10.1016/j.rser.2018.05.055.

[27] D.H.C.Toe, T. Kubota, Comparative assessment of vernacular passive cooling techniques for improving indoor thermal comfort of modern terraced houses in hot-humid climate of Malaysia, Sol. Energy. 114 (2015) 229-258. doi:10.1016/j.solener.2015.01.035. 
[28] P. Moonen, V. Dorer, J. Carmeliet, Evaluation of the ventilation potential of courtyards and urban street canyons using RANS and LES, J. Wind Eng. Ind. Aerodyn. 99 (2011) 414-423. doi:10.1016/j.jweia.2010.12.012.

[29] EnergyPlus, Weather Data | EnergyPlus, (2018). https://energyplus.net/weather (accessed November 2, 2018).

[30] L. Lundström, Shiny weather data, (2018). https://rokka.shinyapps.io/shinyweatherdata/ (accessed June 6, 2018).

[31] ECMWF, Homepage | Copernicus, (2018). https://atmosphere.copernicus.eu/ (accessed August 10, 2019).

[32] Integrated Environmental Solutions, (2018). https://www.iesve.com/ (accessed August 10, 2018).

[33] D.B. Crawley, J.W. Hand, M. Kummert, B.T. Griffith, Contrasting the capabilities of building energy performance simulation programs, Build. Environ. 43 (2008) 661-673. doi:10.1016/j.buildenv.2006.10.027.

[34] M. Kolokotroni, X. Ren, M. Davies, A. Mavrogianni, London's urban heat island: Impact on current and future energy consumption in office buildings, Energy Build. 47 (2012) 302311. doi:10.1016/j.enbuild.2011.12.019.

[35] N. Hamza, Double versus single skin facades in hot arid areas, Energy Build. 40 (2008) 240-248. doi:10.1016/j.enbuild.2007.02.025.

[36] Z. Cheng, L. Li, W.P. Bahnfleth, Natural ventilation potential for gymnasia - Case study of ventilation and comfort in a multisport facility in northeastern United States, Build. Environ. 108 (2016) 85-98. doi:10.1016/j.buildenv.2016.08.019. 
[37] N.A. Al-Tamimi, S.F.S. Fadzil, The Potential of Shading Devices for Temperature Reduction in High-Rise Residential Buildings in the Tropics, Procedia Eng. 21 (2011) 273-282. doi:10.1016/j.proeng.2011.11.2015.

[38] The Charted Institution of Building Services Engineers, CIBSE Guide A: Environmental design, 7th ed., London, 2006.

[39] Integrated Environmental Solutions, IESVE Help Document, (2018). https://help.iesve.com/ve2018/(accessed September 3, 2019).

[40] L. Wang, N.H. Wong, Coupled simulations for naturally ventilated rooms between building simulation (BS) and computational fluid dynamics (CFD) for better prediction of indoor thermal environment, Build. Environ. 44 (2009) 95-112. doi:10.1016/j.buildenv.2008.01.015.

[41] Y. Li, X. Li, Natural ventilation potential of high-rise residential buildings in northern China using coupling thermal and airflow simulations, Build. Simul. 8 (2015) 51-64. doi:10.1007/s12273-014-0188-1.

[42] R. Zhang, K.P. Lam, S. Yao, Y. Zhang, Coupled EnergyPlus and computational fluid dynamics simulation for natural ventilation, Build. Environ. 68 (2013) 100-113. doi:10.1016/j.buildenv.2013.04.002.

[43] O.S. Asfour, M.B. Gadi, A comparison between CFD and Network models for predicting wind-driven ventilation in buildings, Build. Environ. 42 (2007) 4079-4085. doi:10.1016/j.buildenv.2006.11.021.

[44] M. Gijón-Rivera, J. Xamán, G. Álvarez, J. Serrano-Arellano, Coupling CFD-BES Simulation of a glazed office with different types of windows in Mexico City, Build. Environ. 68 (2013) 22-34. doi:10.1016/j.buildenv.2013.06.005. 
[45] Z. (John) Zhai, M.-H. Johnson, M. Krarti, Assessment of natural and hybrid ventilation models in whole-building energy simulations, Energy Build. 43 (2011) 2251-2261. doi:10.1016/j.enbuild.2011.06.026.

[46] K. Arendt, M. Krzaczek, J. Tejchman, Influence of input data on airflow network accuracy in residential buildings with natural wind- and stack-driven ventilation, Build. Simul. 10 (2017) 229-238. doi:10.1007/s12273-016-0320-5.

[47] L. (Leon) Wang, Q. Chen, Evaluation of some assumptions used in multizone airflow network models, Build. Environ. 43 (2008) 1671-1677. doi:10.1016/j.buildenv.2007.10.010.

[48] W. Liu, H. You, J. Dou, W. Liu, J. Dou, H.Y. Beijing, Erratum to: Urban-rural humidity and temperature differences in the Beijing area $\Delta$ e(e Beijing-e Miyun ) (hpa), Theor Appl Clim. 101 (2010) 237-238. doi:10.1007/s00704-008-0024-6.

[49] P.I. Figuerola, N.A. Mazzeo, Urban-rural temperature differences in Buenos Aires, Int. J. Climatol. 18 (1998) 1709-1723. doi:10.1002/(SICI)10970088(199812)18:15<1709::AID-JOC338>3.0.CO;2-I.

[50] E. Krüger, P. Drach, R. Emmanuel, O. Corbella, Urban heat island and differences in outdoor comfort levels in Glasgow, UK, Theor. Appl. Climatol. 112 (2013) 127-141. doi:10.1007/s00704-012-0724-9.

[51] N.E. Theeuwes, A.A.M. Holtslag, L.W.A. van Hove, R.J. Ronda, B.G. Heusinkveld, G.J. Steeneveld, Seasonal dependence of the urban heat island on the street canyon aspect ratio, Q. J. R. Meteorol. Soc. 140 (2013) 2197-2210. doi:10.1002/qj.2289.

[52] M. Taleghani, M. Tenpierik, A. van den Dobbelsteen, D.J. Sailor, Heat in courtyards: A validated and calibrated parametric study of heat mitigation strategies for urban 
courtyards in the Netherlands, Sol. Energy. 103 (2014) 108-124. doi:10.1016/j.solener.2014.01.033.

[53] Y. Gao, R. Yao, B. Li, E. Turkbeyler, Q. Luo, A. Short, Field studies on the effect of built forms on urban wind environments, Renew. Energy. 46 (2012) 148-154. doi:10.1016/J.RENENE.2012.03.005.

[54] M. Taleghani, L. Kleerekoper, M. Tenpierik, A. Van Den Dobbelsteen, Outdoor thermal comfort within five different urban forms in the Netherlands, Build. Environ. 83 (2015) 65-78. doi:10.1016/j.buildenv.2014.03.014.

[55] X.Y. Zhang, B. Chen, Y.Q. Liu, X.L. Han, Analysis on the Relationship between Typical House Mode and Heating Energy Consumption in Cold Rural Areas of Eastern China, Appl. Mech. Mater. 368-370 (2013) 607-610. doi:10.4028/www.scientific.net/amm.368-370.607.

[56] R. Ramponi, A. Angelotti, B. Blocken, Energy saving potential of night ventilation: Sensitivity to pressure coefficients for different European climates, Appl. Energy. 123 (2014) 185-195. doi:10.1016/j.apenergy.2014.02.041.

[57] R.E. Akins, J.A. Peterka, J.E. Cermak, Averaged pressure coefficients for rectangular buildings, in: Wind Eng., Elsevier, 1980: pp. 369-380. doi:10.1016/B978-1-4832-83678.50041-3.

[58] F. Bre, J.M. Gimenez, V.D. Fachinotti, Prediction of wind pressure coefficients on building surfaces using artificial neural networks, Energy Build. 158 (2018) 1429-1441. doi:10.1016/j.enbuild.2017.11.045.

[59] G. Manioğlu, G.K. Oral, Effect of Courtyard Shape Factor on Heating and Cooling Energy Loads in Hot-dry Climatic Zone, Energy Procedia. 78 (2015) 2100-2105. doi:10.1016/J.EGYPRO.2015.11.250. 
